\title{
BIOLOGICAL INTEGRITY OF STREAMS IN THE BIG HOLE RIVER TMDL PLANNING AREA BASED ON THE STRUCTURE AND COMPOSITION OF THE BENTHIC ALGAE COMMUNITY
}

\author{
Prepared for: \\ State of Montana \\ Department of Environmental Quality \\ P.O. Box 200901 \\ Helena, Montana 59620-0901 \\ Contract Officer: Rosie Sada \\ DEQ Contract No. 200012-10
}

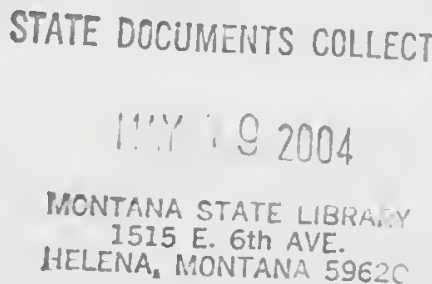

Prepared by:

Loren L. Bahls, Ph.D.

Hannaea

1032 Twelfth Avenue

Helena, Montana 59601

March 2, 2004 
-

- 


\section{Summary}

In the summer of 2003, periphyton samples were collected from 42 sites on 22 streams in the Big Hole River TMDL planning area in southwestern Montana for the purpose of assessing whether these streams are water-quality linited and in need of TMDLs. The samples were collected following MDEQ standard operating procedures, processed and analyzed following standard methods for periphyton, and cvaluated following modified USEPA rapid bioassessment protocols for wadeable streams.

Diatom metrics indicate minor impairment from both organic loading and sedimentation at most of the sites that were sampled for periphyton. However, the pollution index at one siteSwamp Creek site 01 -indicated moderate impairment from excessive organic nutrients and only partial support of aquatic life uses. Siltation index values at Swamp Creek site 01 and Lost Creek site 01 suggest severe impairment from sedimentation and non-support of aquatic life uses. The siltation index value at Sawlog Creek site 01 indicates moderate impairment.

Large percentages of tcratological diatom cells $(>10 \%)$ indicate elevated concentrations of heavy metals and severe impairment of aquatic life uses at both sites on Elkhorn Creek. A smaller percentage of abnormal cells (3-10\%) suggest moderate impairment from heavy metals at Lost Creek site 02. Several other sites supported still smaller percentages of abnormal diatom cells $(<3 \%)$.

Diatoms were present in all of the samples. Most of the 27 major diatom species are either sensitive to organic pollution or only somewhat tolerant of organic pollution. Only two of the major diatom species are most tolerant of organic pollution.

In general, diatom species richness, diversity, and equitability were excellent. Most sites supported more than 50 species and diversity values greater than 4.00 . Ninety species were counted in one sample (LMCHC02) and another site (MCVYC01) had a diversity index of 5.22. These are exceptionally high values for mountain streams. Only one stream (Elkhorn Creek) had diversity values that indicated unusual stress. At only two sites, both on Elkhorn Creek, did the dominant specics contribute more than half of the cells to the diatom assemblage.

High diatom diversity in these streams infers the absence of natural stressors, such as steep gradients, fast currents, low light, low nutrients, and/or constant cold temperatures. The predominance of non-motile, free-living taxa relative to attached species implies that most sites have gentle gradients and slow current velocities compared to other mountain streams. This is confirmed by the comparatively low disturbance index at most sites.

Besides the absence of natural stressors, high diaton diversity in these streams also suggests moderate nutrient enrichment (little competition for available nutrients) and complex microhabitats that are more similar to prairie streams. Pollution index values, which indicate the amount of organic loading, are generally low for mountain strcams. Many are at or below the threshold for minor impairment. Similarly, siltation index values tend to be higher in Big Hole tributaries than in most mountain streams. 


\section{Introduction}

This report evaluates the biological integrity ${ }^{1}$, support of aquatic life uses, and probable causes of stress or impairment to aquatic communities at 42 sites on 22 streams in the Big Hole River TMDL Planning Area of southwestem Montana. The purpose of this report is to provide information that will help the State of Montana determine whether these streams are waterquality limited and in need of TMDLs.

The federal Clean Water Act directs states to develop water pollution control plans (Total Maximum Daily Loads or TMDLs) that set limits on pollution loading to water-quality limited waters. Water-quality limited waters are lakes and stream segments that do not meet waterquality standards, that is, that do not fully support their beneficial uses. The Clean Water Act and USEPA regulations require each state to (1) identify waters that are water-quality linited, (2) prioritize and target waters for TMDLs, and (3) develop TMDL plans to attain and maintain. water-quality standards for all water-quality limited waters.

Evaluation of aquatic life use support in this report is based on the species composition and structure of periphyton (aka benthic algae, phytobenthos) communities at 42 sites on 22 streams that were sampled in the summer of 2003. Periphyton is a diverse assortment of simple photosynthetic organisms called algae that live attached to or in close proximity of the stream bottom. Some algae form long filaments or large gelatinous colonies that are conspicuous to the unaided eye. But most algae, including the ubiquitous diatoms, can be seen and identified only with the aid of a microscope. The periphyton community is a basic biological component of all aquatic ecosystems. Periphyton accounts for much of the primary production and biological diversity in Montana streams (Bahls et al. 1992). Plafkin et al. (1989) and Barbour et al. (1999) list several advantages of using periphyton in biological assessments.

\footnotetext{
"Biological integrity is defined as "the ability of an aquatic ecosystem to support and maintain a balanced, integrated, adaptive communily of organisms having a species composition, diversity, and funclional organization comparable to that of natural habitats within a region" (Karr and Dudley 1981).
} 


\section{Project Area and Sampling Sites}

The project area is located within the Middle Rockies Ecoregion (USEPA 2000). The Big Hole watershed occupies a high mountain basin in the southwestern corner of Montana. The surface geology of the watershed is complex, consisting mostly of Belt Series and Boulder and Idaho Batholith Rocks in the uplands and Tertiary basin fill in the Big Hole Valley (Renfro and Feray 1972). Climax vegetation consists of alpine tundra at the highest elevations, Douglas-fir and subalpine fir forest at intermediate elevations, and mixed grassland/sagebrush steppe in the Big Hole Valley. The main land uses are recreation, logging, ranching, and mining.

Periphyton samples were collected at 42 sites on 22 tributaries of the Big Hole River (Table 1). All sites are in USGS HUC 10020004 and are classified either A-1 or B-1 in the Montana Surface Water Quality Standards depending on whether they are above or below the Butte Water Company intake at Divide, Montana.

\section{Methods}

Periphyton samples were collected following standard operating procedures of the MDEQ Planning, Prevention, and Assistance Division. Using appropriate tools, microalgae were scraped, brushed, or sucked from natural substrates in proportion to the importance of those substrates at each study site. Macroalgae were picked by hand in proportion to their abundance at the site. All collections of microalgae and macroalgae were pooled into a common container and preserved with Lugol's (IKI) solution.

The samples were examined to estimate the relative abundance of cells and rank by biovolume of diatoms and genera of soft (non-diatom) algae according to the method described in Bahls (1993). Soft algae were identified using Smith (1950), Prescott (1962, 1978), John et al. (2002), and Wehr and Sheath (2003). These books also served as references on the ecology of the soft algae, along with Palmer $(1969,1977)$. 
After the identification of soft algae, the raw periphyton samples were cleaned of organic matter using sulfuric acid, potassium dichromate, and hydrogen peroxide. Then permanent diatom slides were prepared using Naphrax ${ }^{\mathrm{TM}}$, a high refractive index mounting medium, following Standard Methods for the Examination of Water and Wastewater (APHA 1998). At least 300 diatom cells ( 600 valves) were counted at random and identified to species. The following were the main taxonomic references for the diatoms: Krammer and Lange-Bertalot 19S6, 1988, 1991 a, 1991b; Lange-Bertalot 1993, 2001; Krammer 1997a, 1997b, 2002; Reichardt 1997, 1999. Diatom naming conventions followed those adopted by the Integrated Taxonomic Information System (http://www. itis.usda.gov). Van Dam et al. (1994) was the main ecological reference for the diatoms.

The diatom proportional counts were used to generate an array of diatom association metrics. A metric is a characteristic of the biota that changes in some predictable way with increased human influence (Barbour et al. 1999). Diatoms are particularly useful in generating metrics because there is a wealth of information available in the literature regarding the pollution tolerances and water quality preferences of common diatom species (e.g., Lowe 1974, Beaver 19S1, Lange-Bertalot 1996, Van Dam et al. 1994).

Values for selected metrics were compared to biocriteria (numeric thresholds) developed for streams in the Rocky Mountain ecoregions of Montana (Table 2). These criteria are based on netric values measured in least-impaired reference streams (Bahls et al. 1992) and metric values measured in streams that are known to be impaired by various sources and causes of pollution (Bahls 1993). The criteria in Table 2 are valid only for samples collected during the summer field season (June 21-September 21) and distinguish among four levels of stress or impairment and three levels of aquatic life use support: (1) no impairment or only minor impaiment (full support); (2) moderate impairment (partial support); and (3) severe impairment (nonsupport). These impaiment levels correspond to excellent, good, fair, and poor biological integrity, respectively. In cold, high-gradient mountain streams, natural stressors will often mimic the effects of man-caused impairment on some metric values. 


\section{Quality Assurance}

Several steps were taken to assure that the study results are accurate and reproducible. Upon receipt of the samples, station and sample attribute data were recorded in the Montana Diatom Database and the samples were assigned a unique number, c.g., 2960-01. The first part of this number (2960) designates the sampling site (Doolittle Creek below North Fork) and the sccond part (01) designates the number of periphyton samples that that have been collected at this site for which data have been entered into the Montana Diatom Database.

Sample observations and analyses of soft (non-diatom) algae were recorded in a lab notebook along with information on the sample label. A portion of the raw sample was used to make duplicate diatom slides. The slides used for the diatom proportional counts will be deposited in the Montana Diatom Collection at the University of Montana Herbarium (MONTU) in Missoula. Duplicate slides will be retained by Hannaea in Helena. Diatom proportional counts have been entered into the Montana Diatom Database.

\section{Results and Discussion}

Results are presented in Tables 3, 4, 5, and 6 which are located near the end of this report following the references section. Appendix A contains a diatom report for each sample. Each diatom report includes an alphabetical list of diatom species in that sample and their percent abundances, and values for 65 different diatom metrics and ecological attributes.

\section{Sample Notes (Table 3)}

Notes on the contents and condition of each sample are recorded in Table 3. Most samples contained varying amounts of sediment and plant material other than algae.

\section{Non-Diatom Algae (Table 4)}


Thirty-four genera representing five divisions of non-diatom algae were found in samples that were collected from tributaries of the Big Hole River (Table 4). Divisions represented by the most genera were Chlorophyta or green algae (18 genera) and Cyanophyta or cyanobacteria (11 genera). The Division Chrysophyta (yellow-green algae) was represented by three genera and the Divisions Rlodophyta (red algae) and Euglenophyta (euglenoid algae) were represented by one genus each.

Green algae were found in all but 10 samples and cyanobacteria were found in all but 12 samples. Yellow-green algae were found in 15 samples and the red alga Audouinella was found in 10 samples. Euglena, a pollution tolerant euglenoid alga, was found in only one sample (DIVDC01). The number of genera of non-diatom algae ranged from 0 in Soap Creek (01) and Lost Creek (02) to 11 in the North Fork of the Big Hole River.

Nitrogen-fixing Algae. Cyanobacteria that possess a certain type of specialized cell (heterocyst) are capable of fixing molecular or atmospheric nitrogen under aerobic conditions. These algae have a competitive advantage in waters where nitrogen is in short supply relative to phosphorus and other nutrients. Among tributaries of the Big Hole River, algae with heterocysts include Anabaena, Calothrix, Nodularia, Nostoc, and Tolypothrix. Sites where one or more of these genera were common, frequent, or abundant are: DOLTC01, SWMPC01, WRMSC01, WRMSC02, PINECO1 and 02, FOXC01 and 02, FSHTC02, ELKHC01 and 02, and DIVDC02. Nitrogen is most likely the limiting nutrient at these sites.

Mat-forming Filamentous Algae. Large standing crops of filanentous algae can interfere with swimming, boating, fishing, and other water uses. Algal genera in tributaries of the Big Hole River that are known to produce nuisance growths in North American waters are Cladophora, Oedogonium, Oscillatoria, Spirogyra, Stigeoclonium, and Ulothrix (Wehr and Sheath 2003). Sites where one or more of these genera were dominant or abundant in periphyton samples are: BGHNF01 and 02, JERRC01, LMCHC02, FRANC02, and DIVDC01. Among sites in this sample set, these are the sites that are most likely to support nuisance growths of filamentous algae. 
Pollution-tolerant Algae. Palmer (1969) listed 60 algal genera that are most tolerant of organic pollution. Genera of non-diatom algae in this sample set that are among the top 21 on Palmer's list are Englena (\#1), Oscillatoria (\#2), Scenedesmus (\#4), Stigeoclonium (\#8), Ankistrodesmus (\#10), Phormidium (\#12) Closterium (\#16), and Spirogyra (\#21). Euglena was found in only one sample (DIVDC01), where it was rare. Sites where one or more of the remaining genera were frequent, abundant, or dominant are: WRMSC02, BGHNF01 and 02 , JERRC01, PINEC02, FOXC02, LMCHC02, ELKHC02, and DIVDC01. These sites are the ones that most likely receive the heaviest loads of organic pollution. Genera among the 21 most pollution-tolerant algae ivere common at several more sites.

Other Indicator Algae. When abundant, certain genera of algae can provide useful clues about environmental conditions. The three genera of chrysophytes that were present in these samples are all good indicator algae. Tribonema, which is sensitive to organic pollution and prefers cool waters, was most abundant in Fishtrap Creek. Vaucheria, another chrysophyte, requires steady flows of cool water. Vaucheria was also abundant in Fishtrap Creek. A third chrysophyte - Hydrurus foetidus - is a cold-water stenotherm that requires waters of constant low temperature. Hydrurus was found only in upper Gold Creek, where it was abundant.

Draparnaldia is a relatively rare filamentous green alga that is most often found in pristine upland streams and springs. It also tends to be more abundant in cooler waters (Wehr and Sheath 2003). Draparnaldia was found only at PINEC01, where it was abundant.

The filamentous green alga Mougeotia has often been reported to increase in abundance in lakes that are subject to atmospheric deposition and undergoing acidification. Among study sites in the Big Hole TMDL planning area, Mougeotia occurred infrequently and was abundant only at the lower site on Elkhorn Creck (ELKHC02).

The foliose, seaweed-like green alga Prasiola has been reported as abundant at sites that are enriched with forms of organic nitrogen, such as bird droppings, as well as in cold mountain streams (Wehr and Sheath 2003). Prasiola was found only at the upper site on Gold Creek, where it was dominant. 


\section{Diatoms (Table 5)}

Diatoms were present in all of the samples. Most of the 27 major diatom species in tributaries of the Big Hole River are either sensitive to organic pollution or only somewhat tolerant of organic pollution. Only two of the major diatom species (Navicula minima and Nitzschia palea) are most tolerant of organic pollution (Table 5).

In general, diatom species richness, diversity, and equitability were excellent. Most sites supported more than 50 species and diversity values in excess of 4.00. One site ( $\mathrm{LMCHC02)}$ had 90 species and another (MCVYCOI) had a diversity index of 5.22. These are exceptionally high values for mountain streams. Only one stream (Elkhorn Creek) had diversity values that indicated unusual stress. At only two sites, both on Elkhorn Creek, did the dominant species contribute more than half of the cells to the diatom assemblage (Table 5).

High diatom diversity in these streams infers the absence of natural stressors, such as steep gradients, fast currents, low light, low nutrients, and constant cold temperatures. The predominance of non-motile, free-living taxa (Diatoma mesodon, Fragilaria spp., Melosira varians, Meridion circulare, Pseudostarosira brievistriata, Staurosira construens, Staurosirella spp., Synedra ulna) relative to attached species (Achnanthidium spp., Cocconeis placentula) implies that most sites have gentle gradients and slow current velocities compared to other mountain streams. This is confirmed by the comparatively low disturbance index at most sites (Table 5).

Besides the absence of natural stressors, high diatom diversity in these streams also suggests moderate nutrient enrichment (little competition for available nutrients) and complex microhabitats that are more similar to prairie streams. Pollution index values, which indicate the amount of organic loading, are generally low for mountain streams. Many are at or below the threshold for minor impairment. Similarly, siltation index values tend to be higher in Big Hole tributaries than in most monntain streams. 
Many of the sites supported teratological (deformed or physically abnormal) diatom cells. In large numbers, abnormal cells may indicate metals toxicity. The percentage of abnormal cells was within acceptable limits in all streams except Elkhom Creek and Lost Creek (Table 5).

Similarity index values indicate that ecological changes between adjacent sites on the same stream varied from un-measurable $(>60 \%)$ to minor $(40-60 \%)$ to moderate $(20-40 \%)$. The similarity index ("percent community similarity") measures the cumulative percentage of cells of each taxon that are shared by two stream sites. If diatom metrics indicate that the upstream site has no impairment or only minor impairment, then the similarity index can be used to estimate the degree of impairment that may or may not occur at downstrean sites on the same stream.

The diatom order Rhopalodiales includes genera (Epithemia and Rhopalodia) that are known to harbor nitrogen-fixing endosymbionts within their cells. These symbiotic nitrogenfixers are single-celled cyanobacteria (blue-green algae). Nitrogen is likely the limiting nutrient in waters that support large numbers of diatoms in the order Rhopalodiales. Among tributaries to the Big Hole River, diatoms in the order Rhopalodiales accounted for more than $2 \%$ of the cells at the following sites: FRANC02 (25.39\%), DIVD01 (3.46\%), DIVD02 (3.24\%), MCVYC01 $(2.73 \%)$, and CAMPC03 (2.05\%).

The following paragraphs highlight the key findings for each stream and each site based upon the major diatom species and core diatom metrics in Table 5.

Doolittle Creek. Aside from a few teratological diatom cells, both sites on Doolittle Creek had excellent biological integrity. However, values for both the pollution index and the sedimentation index approached (but did not exceed) the threshold for minor impairnent at the downstream site (Table 5). The two sites shared $56 \%$ of their diaton assemblages. This indicates that only minor floristic and ecological change occurred between them. The dominant diatom species at the upstream site (Diatoma mesodon) indicates consistently cold water. 
McVey Creek. Diatom metrics indicate minor impairment from organic loading and sedimentation at site 01. An abundance of Staurosira constmens and Pseudostaurosira brevistriata at site 02 indicates gentle gradients and very little physical disturbance. Both sites supported a few teratological diatom cells. The two sites shared less than $40 \%$ of their diatom floras, which indicates a moderate change in environmental conditions.

Swamp Creek. Diatom metrics suggest moderate impairment from organic loading and severe impairment from sedimentation at site 01 on Swamp Creek. Cells of the motile genera Navicula and Nitzschia accounted for three-quarters of the diatoms in the sample from site 01. One of the major species ivas Nitzschia palea, a nitrogen heterotroph that is very tolerant of organic pollution. Conditions were somewhat better at site 02 , where diatom metrics indicate only minor impairment from organic loading and sedimentation. However, one of the major species at site 02 was Navicula minima, which is also very tolerant of organic enrichment. Both sites had a few abnormal diatom cells and shared only about one-third of their assemblages.

Warm Springs Creek. Site 01 on Warn Springs Creek supported a large number of Navicula minima, an eutraphentic nitrogen heterotroph. This resulted in a depressed pollution index that suggests minor impairment from organic loading. Elevated percentages of motile diatoms suggest minor impairment from sedimentation at both sites. A larger percentage of Achnanthidium minutissimum suggests steeper gradients and more physical disturbance at site 02. Both sites supported a few teratological cells and they shared slightly less than half of their diatom assemblages.

North Fork Big Hole River. The pollution index at both sites was close to the threshold for minor impairment from organic loading. Sedimentation was also a minor problem at both sites. Site 02 supported $50 \%$ more motile diatons than site 01 and the siltation index at site 02 approached (but did not exceed) the threshold for moderate impairment. The dominant species at site 02 was a highly motile species of Nitzschia ( $N$. archibaldii). The other major species here indicate somewhat gentler gradients and slower current velocities than site 01 . Both sites had a few abnormal cells and they shared slightly more than half of their diatom assemblages. 
Gold Creek. The two sites on Gold Creek had very similar values for most metrics and were virtually indistinguishable in terms of diatom species composition. Both sites had pollution index values that indicate minor organic enrichment and both supported a few abnormal diatom cells. Although the sedimentation index at both sites did not exceed the threshold for minor impairment, both sites supported large numbers of Planothidium spp., which is adapted to living attached to sand grains.

Jerry Creek. The one sample from Jerry Creek was dominated by Fragilaria valucheriae, an "increaser" that is found worldwide in disturbed freshwater habitats. The other major species at this site are common pollution-sensitive species and indicate gentle gradients and slow current velocities. The pollution index at this site approached but did not exceed the criterion for minor impairment. A few teratological cells were found here.

Pine Creek. Like Gold Creek, the two sites on Pine Creek had similar diatom floras and similar metric values. Both sites had sedimentation index values that barely exceed the threshold for minor impairment. Pollution index values approached, but did not exceed, the threshold for minor impairment. Major diatom species indicate eutrophic waters (enriched with inorganic nutrients) and gentle gradients at both sites. A few abnormal cells were also recorded here.

Fox Creek. Diatom metrics indicate minor impairment from organic loading and sedimentation at both sites on Fox Creek. Major diatom species indicate human disturbance with elevated nutrients at both sites. Planothidium species, which are adapted to living attached to sand grains, was a major taxon at site 01 . A few deformed cells were counted at site 02 and the two sites shared $54 \%$ of their diatom floras.

Fishtrap Creck. The pollution index indicated minor impairment from organic loading at site 01 and borderline impairment at site 02 . The siltation index indicated minor impairment from sedimentation at site 02 . Major diatom species indicate gentle gradients at both sites and human disturbance with elevated nutrients, especially at site 01 . A few abnomal cells were counted at site 01 . The diatom floras at the two sites were virtually indistinguishable. 
LaMarche Creek. Except for several abnormal cells at site 02, both sites had excellent biological integrity. Diatom species richness, diversity, and equitability were outstanding. Both sites supported more than 80 species (90 species at site 02!) and produced Shannon diversity values greater than 5. Among the major species in LaMarche Creek was Aulacoseira alpigena, a planktonic species. The headwaters of LaMarche Creek drain several lakes and ponds in the Anaconda Pintler Wilderness. These waters are the likely source of $A$. alpigena in LaMarche Creek and the main reason for the unusually high species richness and diversity here. The two sites shared slightly more than half of their diatom floras.

Delano Creek. Diatom metrics indicate excellent biological integrity and full support of aquatic life uses at sites 01 and 02 on Delano Creek. None of the core metric values exceeded their respective thresholds for minor impairment here. However, an abundance of Planothidium species suggests sandy substrates at both sites. Other than Planothidium, the major species at sites 01 and 02 were sensitive to pollution and indicate cold temperatures. Based on the larger percentage of attached diatoms (Achnanthidium and Cocconeis), sites 01 and 02 appear to have steeper gradients and faster currents than most of the other sites in the sample set. The diatom assemblages at sites 01 and 02 were virtually identical.

The pollution index indicated minor impairment from organic enrichment at site 03 . The composition of the diatom assemblage here was quite different from sites 01 and 02 . Site 03 supported large numbers of unattached diatoms (Fragilaria and Synedra) and fewer attached species, which indicates more gentle gradients and slower current velocities. Although an abundance of Diatoma mesodon and Meridion circulare indicate a continuation of cool water temperatures here, site 03 also supported major species that indicate human disturbance with elevated sediment (Planothidium spp.) and inorganic nutrients (Synedra ulma). Fragilaria nitzschioides was also a major species at site 03 . This rather uncommon pollution sensitive species seems to prefer slightly dystrophic waters of low mineral content. No abnormal diatom cells were observed at site 03 , which shared less than half of its diatom assemblage with site 02 .

Charcoal Gulch. Diatom metrics indicate minor impairment from sedimentation and organic loading at this site. The dominant diatom species here (Planothidium) are adapted to 
living on sand grains and collectively they indicate a sandy substrate. The other major specicsNitzschia linearis and Synedra ulna-indicate human disturbance and eutrophication. Nitzschia linearis is highly motile and adapted to living on shifting substrates. Charcoal Gulch did not support any teratological diatom cells.

Elkhorn Creek. Large percentages of abnormal diatom cells (>10\%) suggest severe impairment from toxic metals at both sites on Elkhorn Creek. Moreover, diatom species diversity at these sites was significantly lower than all of the other sites in the sample set. Both sites were dominated by Achnanthidium minutissimum. This species tolerates elevated concentrations of heavy mctals and, when present in large numbers, indicates probable physical, chemical, and/or biological disturbance. Two pollution-tolerant species of Fragilaria were also anıong the major species at site 02 . Sites 01 and 02 were virtually identical, floristically.

Francis Creek. Diatom metrics indicate minor impairment from sedimentation at both sites and minor impairment from organic loading at site 01 . This organic loading may be natural in origin. Major species at site 01 show the influence of upstrcam lakes or ponds (Aulacoseira alpigena), elevated inorganic nutrients (Melosira varians), sandy substrates (Planothidium spp.), and low current velocities (Staurosira construens). An abundance of unattached diatoms (Pseudostaurosira brevistriata, Staurosira construens) also indicates a gentle gradient at site 02. The other major species at site 02 (Epithemia sorex) is a nitrogen fixer and indicates low ambient concentrations of biologically available nitrogen. Abnormal diatom cells were not observed at either site. The two sites shared less than one-third of their diatom assemblages, indicating that a moderate amount of environmental changes occurred between them.

Divide Creek. Minor organic loading and minor, approaching moderate sedimentation was indicated at site 01 on Divide Creek. The major diatom species here indicate alkaline and eutrophic waters. Although no impairment was noted at site 02 , both the pollution index and the siltation index approached their respective thresholds for minor impairment. The appearance of Planothidinm species and Cocconeis placentula among the major species at site 02 suggests the presence of sandy substrates. No abnormal diatom cells were observed at either site. They shared less than half of thcir diatom assemblages. 
Soap Creek. Minor impairment from sedimentation was indicated at both sites on Soap Creek. Planothidium species were dominant at both sites. Minor impairment from organic loading was indicated at site 01 and borderline impairment from organic loading was noted at site 02. Major diatom species indicate slower current velocities at site 01 and more physical disturbance at site 02. Abnormal cells were not observed at either site and the two sites supported very similar diatom floras.

MacLean Creek. Diatom metrics indicate minor impairment from sedimentation and organic loading in MacLean Creek. The dominant diatom species at this site (Planothidium lanceolatum) is adapted to living attached to grains of sand. Another major species at this site (Nitzschia linearis) is highly motile and adapted to living on shifting substrates composed of finc sediments. A few abnormal diatom cells were observed in the sample from MacLean Creek.

Grose Creek. Diatom metrics indicate minor impairment from organic loading and borderline moderate impairment from sedimentation in Grose Creek. Planothidinm species dominated the diatom assemblage of Grose Creek, as they did in MacLean Creek. Nitzschia linearis was also a major species in Grose Creek. No abnormal diatom cells were observed in the sample from Grose Creek.

Lost Creek. A large number of highly motile diatoms indicates severe impairment from sedimentation at site 01 on Lost Creek. In addition, the pollution index value at site 01 approached the criterion for moderate impairment from organic loading. The doninant species here was Nitzschia inconspicua. Besides being highly motile, this species is eutraphentic and a facultative nitrogen heterotroph. Navicula minima was another major species at site 01 . This species is also a motile, eutraphentic, nitrogen heterotroph. A few abnormal cells were observed in the sample collected at site 01 .

Much less organic loading and sedimentation were observed at site 02 , where the pollution index indicated no impairment and the sedimentation index indicated only minor impairment. Cocconeis placentula, Planothidium species, and Rhoicosphenia abbreviata 
replaced Nitzschia inconspicua and Navicula minima as major species at site 02 . The first two indicate the presence of sandy substrates at site 02 . All three species toleratc eutrophic conditions but much less organic loading than $N$. inconspicua and $N$. minima. Site 02 did support $3.88 \%$ abnormal diatom cells, which suggests moderate impairment from elevated heary metals. The two sites on Lost Creek shared only about one-third of their diatom floras.

Sawlog Creek. Diatom metrics suggest moderate impairment from sedimentation and minor impairment from organic loading at site 01 on Sawlog Creek. This was one of the few sites where motile Navicula species ( $N$. capitatoradiata and $N$. reichardtiana) were abundant. Like these Naviculas, the other major species here (Encyonema silesiacum and Planothidium species) are also eutraphentic and somewhat tolerant of organic enrichment.

Diatom metrics at site 02 on Sawlog Creek indicate somewhat less organic loading and sedimentation than site 01, but still within the range of minor impairment. In addition to the eutraphentic Encyonema silesiacum, the major species at site 02 indicate elevated inorganic nutrients (Synedra ulna) and slower current velocities (Staurosira construens). No abnormal diatom cells were observed at either site 01 or site 02 , which shared about half of their diatom assemblages.

Camp Creek. All three sites on Camp Creek suffered minor impairment from sedimentation, which approached moderate impairment at sites 02 and 03 . Planothidium species and the highly motile Nitzschia linearis were among the major species at sites 02 and 03 , but not at 01 . The dominant diatom at site 01 was the attached and pollution sensitive species Achnanthidium affine. Organic loading was also a minor problem at site 02 . The pollution index at sites 01 and 03 approached but did not exceed the threshold for minor impairment. Abnormal diatom cells were not observed in any of the Camp Creek samples. Sites 01 and 02 were very different from one another, floristically, sharing only about one-quarter of their diatom floras. Sites 02 and 03 were nearly as different and shared only about one-third of their assemblages. 


\section{Modal Categories (Table 6)}

Several ecological attributes assigned by Stevenson and Van Dam et al. (1994) were selected from the diatom reports in the appendix and modal categories of these attributes were extracted to characterize water quality tendencies in tributaries of the Big Hole River (Table 6).

The majority of diatoms at most sites in the Big Hole TMDL planning area were nonmotile, alkaliphilous, nitrogen autotrophs that prefer fresh waters, moderate BOD levels, high oxygen levels, and eutrophic conditions or variable levels of inorganic nutrients. However, the modal categories at some sites represent significant departures in water quality when compared to most other sites in the sample set. These departures, which may reflect increases or decreases in water quality, are discussed below.

Although most of the sites were dominated by non-motile diatoms, SWMPC01 and LOSTC01 were dominated by highly motile diatoms and SWLGC01 was dominated by moderately motile diatoms. These are the sites that are most likely to have sedimentation problems.

Diatom species that prefer circumneutral (as opposed to alkaline) pH values were most abundant at SWMPC01, LMCHCO1, and ELKHCO1 and 02. These sites are likely to have lower $\mathrm{pH}$ values than the remaining sites.

Nitrogen autotrophs were in the majority at all sites except LOSTC01 and CAMPC01. At site 01 on Lost Creek, facultative heterotrophs (mainly Navicula minima and Nitzschia inconspicua) accounted for the majority of the diaton cells. This site likely receives heavier loads of organic nitrogen than other sites in the sample set. At site 01 on Camp Creek, most cells were represented by species that have not been classified with regard to nitrogen uptake (e.g., Achnanthidium affine).

The modal category for oxygen demand was less than "continuously high" at several sites. Most diatoms were in the "fairly high" category at SWMPC0I and DIVDC0I and 02. 
Moderate oxygen demand was the modal category at MCVYC01, SWMPC02, GOLDC02, FOXC02, DLNOC01 and 03, CHRGC01, CAMPC02 and 03, and at all stations in Soap Creek, MacLean Creek, Grose Creek, Lost Creek, and Sawlog Creek. At site 01 on Camp Creek, most cells were represented by species that have not been classified with regard to oxygen demand (e.g., Achnanthidium affine).

Beta-mesosaprobous was the usual level of saprobity at most sites. This represents a dissolved oxygen saturation level of 70-85\% and 2-4 $\mathrm{mg} / \mathrm{L}$ of biochemical oxygen demand $\left(\mathrm{BOD}_{5}\right)$. But saprobity levels were higher or lower than this level at some sites. Sites where most of the diatoms indicated more organic loading (alpha-mesosaprobous) were GOLDC02, CHRGC01, FRANC01, MCLNC01, LOSTC01, and SWLGC01. The alpha-mesosaprobous level corresponds to $25-70 \%$ saturation of dissolved oxygen and $4-13 \mathrm{mg} / \mathrm{L} \mathrm{BOD}_{5}$. Sites where most of the diatoms indicated less organic loading than usual (oligosaprobous) were DOLTC01, GOLDC01, both sites on LaMarche Creek, and CAMPC01. The oligosaprobous category corresponds to $>85 \%$ oxygen saturation and $<2 \mathrm{mg} / \mathrm{L} \mathrm{BOD}_{5}$.

At two sites the majority of diatoms represented species that prefer lower concentrations of inorganic nutrients than indicated at most of the other sites. Site 01 on LaMarche Creek (LMCHC01) was dominated by oligotraphentic diatom species (e.g., Aulacoseira alpigena). Oligotraphentic is the lowest (least enriched) nutrient category. Site 02 on McVey Creek (MCVYC02) was dominated by meso-eutraphentic species (e.g., Staurosira construens). Mesoeutraphentic is the next level below (less enriched than) eutraphentic. 


\section{References}

APHA. 1998. Standard Methods for the Examination of Water and Wastewater. 20 $0^{\text {th }}$ Edition. American Public Health Association, Washington, D.C.

Bahls, L.L. 1979. Benthic diatom diversity as a measure of water quality. Proceedings of the Montana Acadenyy of Sciences 38:1-6.

Bahls, L.L. 1993. Periphyton Bioassessment Methods for Montana Streams (revised). Montana Department of Health and Environmental Sciences, Helena.

Bahls, L.L., Bob Bukantis, and Steve Tralles. 1992. Benchmark Biology of Montana Reference Streams. Montana Department of Health and Environmental Sciences, Helena.

Barbour, M.T., J. Gerritsen, B.D. Snyder, and J.B. Stribling. 1999. Rapid Bioassessment Protocols for Use In Streams and Wadeable Rivers: Periphyton, Benthic Macroinvertebrates and Fish. Second Edition. EPA/841-B-99-002. U.S. Environmental Protection Agency, Office of Water, Washington, D.C.

Beaver, Janet. 1981. Apparent Ecological Characteristics of Some Common Freshwater Diatoms. Ontario Ministry of The Environment, Technical Support Section, Don Mills, Ontario.

Hieber, Maggi, C.T. Robinson, S. R. Rushfortl, and Urs Uehlinger. 2001. Algal communities associated with different alpine stream types. Arctic, Antarctic, and Alpine Research 33(4):447-456.

Joliansen, J.R. 1999. Diatoms of Aerial Habitats. Chapter $12 \mathrm{in}$ Stoermer, E.F., and J.P. Smol (eds.), The Diatons: Applications For the Environmental and Earth Sciences, Cambridge University Press, New York.

John, D.M., B.A. Whitton, and A.J. Brook (eds.). 2002. The Freshwater Algal Flora of the British 1sles: An Identification Guide to Freshwater and Terrestrial Algae. Cambridge University

Karr, J.R., and D.R. Dudley. 1981. Ecological perspectives on water quality goals. Environmental Management 5:55-69.

Kawecka, B. 1990. The effect of flood-control regulation of a montane stream on the communities of sessile algae. Acta Hydrobiology 32:345-354.

Krammer, Kurt. 1997a. Die cymbelloiden Diatomeen: Eine Monographie der weltweit bekannten Taxa. Teil 1. Allgemeines and Encyonema Part. J. Cramer, Berlin.

Krammer, Kurt. 1997b. Die cymbelloiden Diatomeen: Eine Monographie der weltweit bekannten Taxa. Teil 2. Encyonema part., Encyonopsis and Cymbellopsis. J. Cramer, Berlin.

Krammer, Kurt. 2002. Cymbella. Volume 3 in Diatoms of Europe, Horst Lange-Bertalot, ed. A.R.G. Gantner Verlag K.G., Germany.

Kramner, K., and H. Lange-Bertalot. 1986. Bacillariophyceae, Part 2, Volume 1: Naviculaceae. In Ettl, H., J Gerloff, 11. Heynig, and D. Mollenhauer (eds.), Freshwater Flora of Middle Europe. Gustav Fischer Publisher, New York.

Krammer, K., and H. Lange-Bertalot. 1988. Bacillariophyceae, Part 2, Volume 2: Bacillariaceae, Epithemiaceae, Surirellaceae. In Ettl, H., J. Gerloff, H. Heynig, and D. Mollenhauer (eds.), Freshwater Flora of Middle Europe. Gustav Fischer Publisher, New York. 
Kranmer, K., and H. Lange-Bertalot. 1991a. Bacillariophyceae, Part 2, Volume 3: Centrales, Fragilariaceae, Eunotiaceae. In Ettl, H., J. Gerloff, H. Heynig, and D. Mollenlauer (eds.), Freshwater Flora of Middle Europe. Gustav Fischer Publisher, Stuttgart.

Kranmer, K., and H. Lange-Bertalot. 1991b. Bacillariophyceae, Part 2, Volume 4: Achnanthaceae, Critical Supplement to Navicula (Lincolatae) and Gomphonema, Complcte List of Literature for Volumes 1-4. In Ettl, H., G. Gartner, J. Gerloff, H. Heynig, and D. Mollenhauer (eds.), Freshwater Flora of Middle Europe. Gustav Fischer Publisher, Stuttgart.

Lange-Bertalot, Horst. 1979. Pollution tolcrance of diatoms as a criterion for water quality estimation. Nova Hedwigia 64:285-304.

Lange-Bertalot, Horst. 1993. 85 new taxa and much morc than 100 taxonomic clarifications supplementary to Susswasserflora von Mitteleuropa Vol. 2/1-4. J. Cramer, Berlin.

Lange-Bertalot, Horst. 1996. Rote Liste der limnischen Kieselalgen (Bacillariophyceae) Deutschlands. Schr.-R. f. Vegetationskde., H. 28, pp. 633-677. BfN, Bonn-Bad Godesberg.

Lange-Bertalot, Horst. 2001. Navicula sensu stricto: 10 Genera Separated from Navicula sensu lato; Frustulia Volume 2 in Diatons of Europe, Horst Lange-Bertalot, ed. A.R.G. Gantner Verlag K.G., Germany.

Lowe, R.L. 1974. Environmental Requirements and Pollution Tolerance of Freshwater Diatoms. EPA-670/4-74-005. U.S. Environmental Protection Agency, National Environmental Research Center, Office of Research and Development, Cincinnati, Ohio.

McFarland, B.H., B.H. Hill, and W.T. Willingham. 1997. Abnormal Fragilaria spp. (Bacillariophyceae) In streams impacted by mine drainage. Journal of Freshwater Ecology 12(1):141-149.

Nicholls, K.H., and D.E.Wujek. 2003. Chrysophycean Algae. Chapter 12 (pp. 47l-509) in Wehr, J.D., and R.G. Sheath (eds.), Freshwater Algae of North Amcrica: Ecology and Classification. Academic Press, New York.

Palmer, C.M. 1969. A composite rating of algae tolerating organic pollution. Journal of Phycology 5:78-82.

Palmer, C.M. 1977. Algae and Water Pollution: An Illustrated Manual on the Identification, Significance, and Control of Algae in Water Supplies and in Polluted Water. EPA-600/9-77-036.

Plafkin, J.L., M.T. Barbour, K.D. Porter, S.K. Gross, and R.M. Hughes. 1989. Rapid Bioassessment Protocols for Use in Rivers and Streams: Benthic Macroinvertebrates and Fish. EPA 440-4-89-001.

Prescott, G.W. 1962. Algae of the Western Great Lakes Area. Wm. C. Brown Company, Dubuque, lowa.

Prescott, G.W. 1978. How to Know the Freshwater Algae. Third Edition. Wm. C. Brown Company Publishers, Dubuque, lowa.

Reichardt, Erwin. 1997. Taxononische Revision des Artenkomplexes um Gomphonema pumi/um (Bacillariophyta). Nova Hedwigia 65(1-4):99-129.

Reichardt, Erwin. 1999. Zur Revision der Gattung Gomphonema. A.R.G. Gantner Verlag, Distributed by Koeltz Scientific Books, Konigstcin, Germany.

Renfro, H.B., and D.E. Feray. 1972. Geological Highway Map of the Northern Rocky Mountain Region. American Association of Pctrolcum Geologists, Tulsa, Oklahoma. 
Smith, G.M. 1950. The Fresh-IVater Algae of The United States. McGraw-Hill Book Company, New York.

Stevenson, R.J., and Y. Pan. 1999. Assessing Environmental Conditions in Rivers and Streams with Diatoms. Chapter 2 in Stoermer. E.F., and J.P. Smol (eds.), The Diatoms: Applications For the Environmental and Earth Sciences, Cambridge University Press, New York.

Stewart, W.D.P., P. Rowell, and A.N. Rai. 1980. Symbiotic Nitrogen-Fixing Cyanobacteria. Pp. 239-277 in Stewart, W.D.P., and J. Gallo (eds.), Nitrogen Fixation, Academic Press, New York.

USDA. 1976. Climax Vegetation of Montana (map). U.S. Department of Agriculture, Soil Conservation Service, Cartographic Unit, Portland.

USEPA. 2000. Level III Ecoregions of the Continental United States (map). National Health and Environmental Effects Research Laboratory, U.S. Environmental Protection Agency, Corvallis, Oregon.

Van Dam, Herman, Adrienne Mertens, and Jos Sinkeldam. 1994. A coded checklist and ecological Indicator values of freshwater diatoms from The Netherlands. Netherlands Journal of Aquatic Ecology 28(1):117-133.

Weber, C.I. (ed.). 1973. Biological Field and Laboratory Methods for Measuring the Quality of Surface Waters and Effluents. EPA-670/4-73-001. U.S. Environmental Protection Agency, National Environmental Research Center, Office of Research and Development, Cincinnati, Ohio.

Wehr, J.D., and R.G. Sheath. 2003. Freshwater Algae of North America: Ecology and Classification. Academic Press, New York.

Whittaker, R.H. 1952. A study of summer foliage insect communiries in the Great Smoky Mountains. Ecological Monographs 22:1-44.

Woods, A.J., Omernik, J.M., Nesser, J.A., Shelden, J., and S.H. Azevedo. 1999. Ecoregions of Montana (color poster with map), U.S. Geological Survey, Reston, Virginia. 


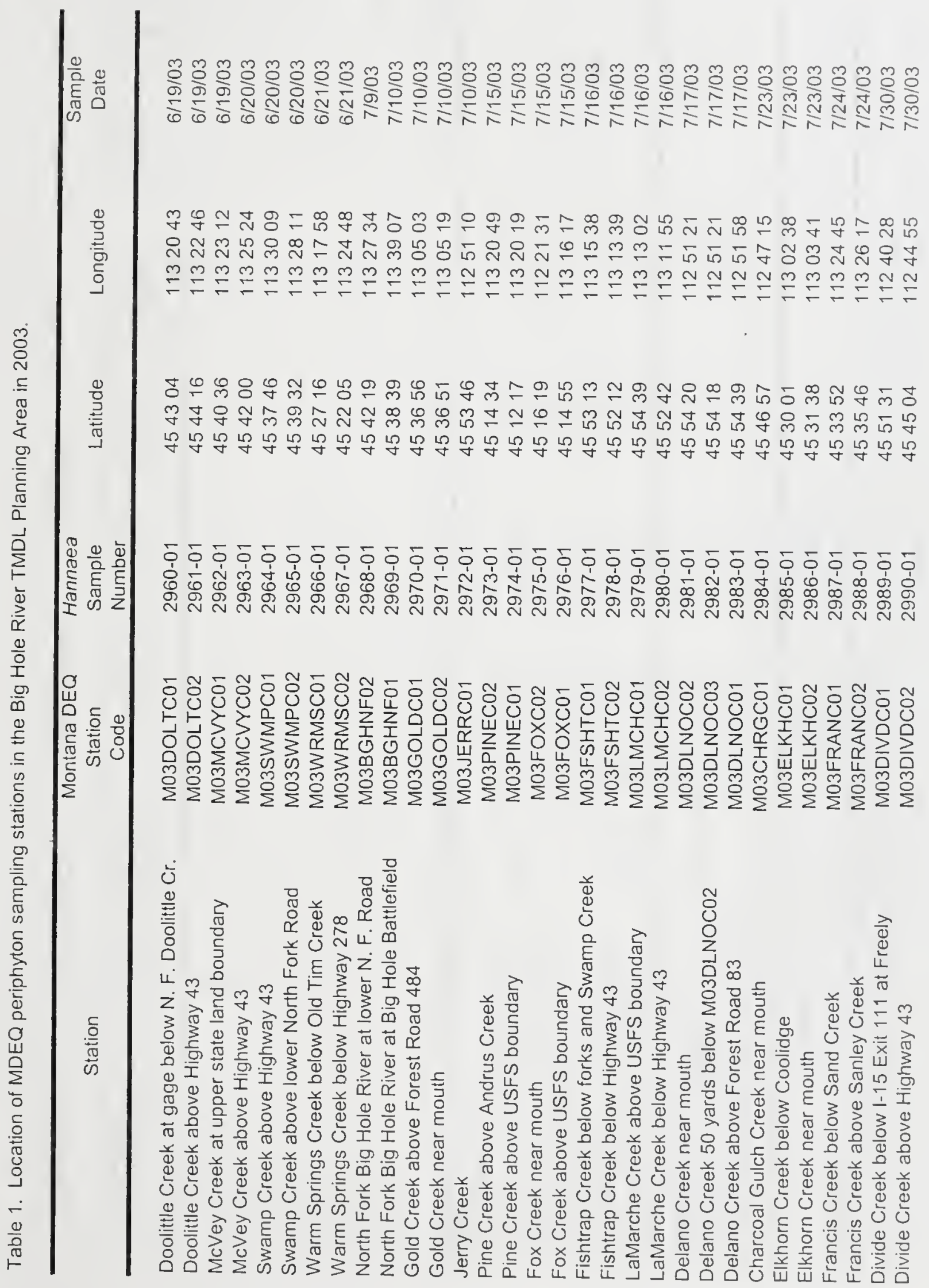




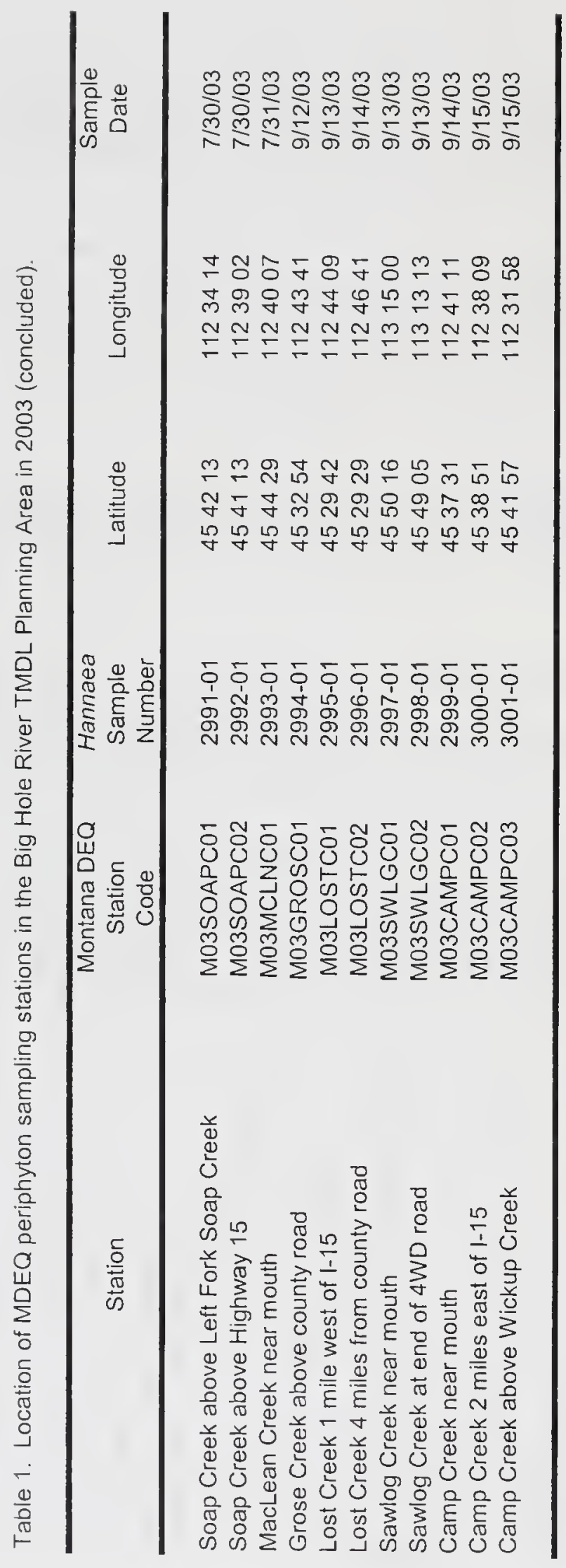




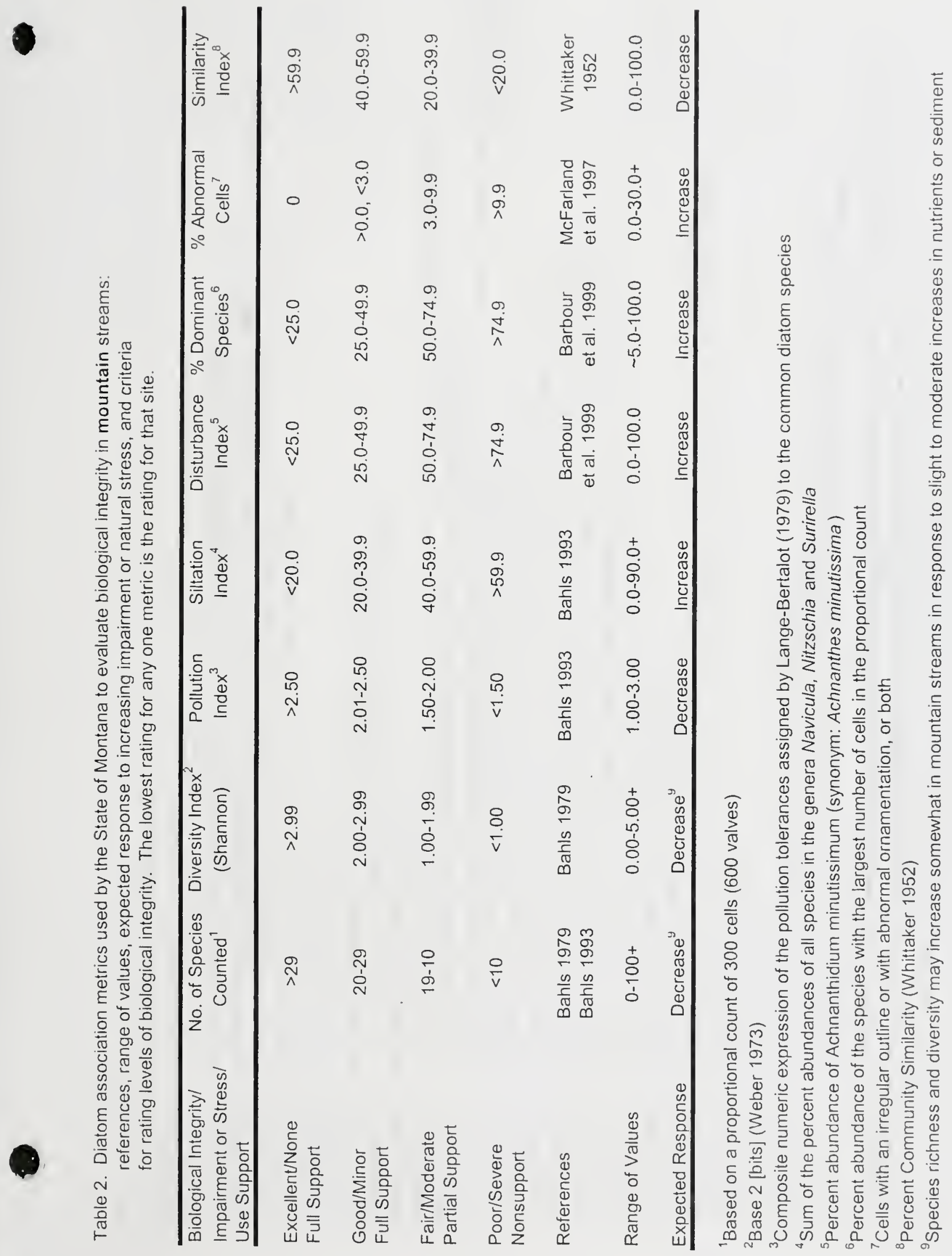




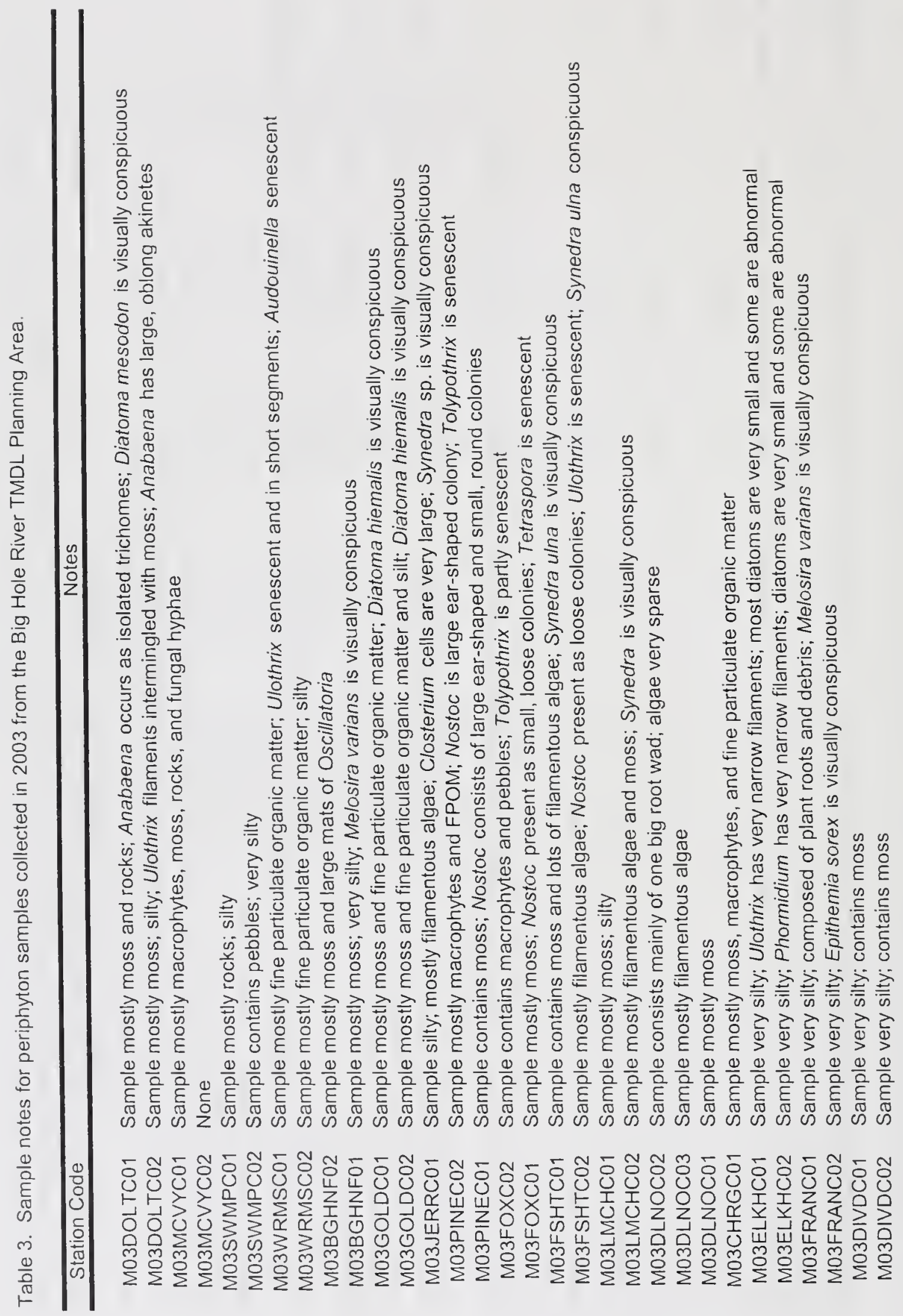




$$
\psi
$$


Table 4. Relative abundance of cells and ordinal rank by biovolume of diatoms (Division Bacillariophyta) and genera of non-diatom algae in periphyton samples collected from the Big Hole River TMDL Planning Area in 2003: $d=$ dominant, $a=$ abundant $f=$ frequent,$c=$ common; $o=$ occasional; $r=$ rare.

Taxa

DOLTC01 DOLTC02 MCVYC01 MCVYC02 SWMPC01 SWMPC02 WRMSC01

Cyanophyta

Amphithrix

Anabaena

Calothrix

Chamaesiphon

Merismopedia

Nodularia

Nostoc

Oscillatoria

Phormidium

Symploca

Tolypothrix

Rhodophyta

Audouinella

\section{Chlorophyta}

Ankistrodesmus

Cladophora

Closterium

Cosmarium

Draparnaldia

Hormidium

Microspora

Mougeotia

Oedogonium

Pediastrum

Prasiola

Scenedesmus

Spirogyra

Staurastrum

Stigeoclonium

Tetraspora

Ulothrix

Zygnema

\section{Euglenophyta \\ Euglena}

\section{Chrysophyta \\ Hydrurus foetidus \\ Tribonema \\ Vaucheria}

f/1

$r / 6$
$o / 5$

c/2 o/5

$0 / 4$

c/3

$0 / 3$ f/2

c/5

$0 / 7$

$0 / 8$

o/6

c/4

$0 / 2$

$0 / 5$

$\mathrm{f} / 2$

f/2

$\Gamma / 7$

$0 / 4$

$c / 3$

$f / 2$

c/3

$c / 4$

o/6

$c / 3$

Bacillariophyta

f/1

a/1

o/1

$\mathrm{c} / 2$

a/1

a/1

$a / 1$

No. Non-Diatom Genera

4

5

2

6

5 
Table 4. Relative abundance of cells and ordinal rank by biovolume of diatoms (Division Bacillariophyta) and genera of non-diatom algae in periphyton samples collected from the Big Hole River TMDL Planning Area in 2003: $d=$ dominant, $a=$ abundant, $f=$ frequent, $c=$ common; $o=$ occasional; $r=$ rare. (continued)

\begin{tabular}{|c|c|c|c|c|c|c|c|}
\hline Taxa & WRMSC02 & BGHNF01 & BGHNF02 & GOLDC01 & GOLDC02 & JERRC01 & PINEC01 \\
\hline \multicolumn{8}{|l|}{ Cyanophyta } \\
\hline \multicolumn{8}{|l|}{ Amphithrix } \\
\hline Anabaena & $a / 1$ & $0 / 8$ & $0 / 9$ & & & & \\
\hline Calothrix & $\mathrm{c} / 5$ & & $0 / 8$ & & & & \\
\hline \multicolumn{8}{|l|}{ Chamaesiphon } \\
\hline \multicolumn{8}{|l|}{ Merismopedia } \\
\hline \multicolumn{8}{|l|}{ Nodularia } \\
\hline Nostoc & & & & & & & $f / 3$ \\
\hline Oscillatoria & $f / 3$ & o/9 & $d / 1$ & $0 / 7$ & & & \\
\hline \multicolumn{8}{|l|}{ Phormidium } \\
\hline \multicolumn{8}{|l|}{ Symploca } \\
\hline Tolypothrix & $\mathrm{c} / 4$ & & & & & & $0 / 6$ \\
\hline \multicolumn{8}{|l|}{ Rhodophyta } \\
\hline Audouinella & $\mathrm{o} / 7$ & & $0 / 6$ & $0 / 8$ & & & \\
\hline \multicolumn{8}{|l|}{ Chlorophyta } \\
\hline Ankistrodesmus & & & $o / 11$ & & & & \\
\hline \multicolumn{8}{|l|}{ Cladophora } \\
\hline Closterium & $r / 9$ & $\mathrm{o} / 7$ & $c / 5$ & $c / 5$ & $\mathrm{c} / 3$ & $\mathrm{c} / 4$ & $\mathrm{c} / 4$ \\
\hline Cosmarium & o/8 & $0 / 6$ & $0 / 7$ & & $0 / 4$ & & \\
\hline Draparnaldia & & & & & & & $a / 1$ \\
\hline \multicolumn{8}{|l|}{ Hormidium } \\
\hline \multicolumn{8}{|l|}{ Microspora } \\
\hline Mougeotia & & $\mathrm{c} / 4$ & & & & & \\
\hline Oedogonium & & $\mathrm{c} / 5$ & & & & & \\
\hline Pediastrum & & & $r / 12$ & & & & \\
\hline Prasiola & & & & $d / 1$ & & & \\
\hline Scenedesmus & & $r / 10$ & $\mathrm{o} / 10$ & & & & \\
\hline Spirogyra & $o / 6$ & $a / 2$ & $c / 4$ & o/6 & & $f / 3$ & \\
\hline Staurastrum & & $r / 11$ & & & & & \\
\hline Stigeoclonium & & & $f / 3$ & & & & \\
\hline Tetraspora & & & & & & & $c / 5$ \\
\hline Ulothrix & & & & & & $d / 2$ & \\
\hline Zygnema & & & & & & $\mathrm{c} / 6$ & \\
\hline \multicolumn{8}{|l|}{$\begin{array}{l}\text { Euglenophyta } \\
\text { Euglena }\end{array}$} \\
\hline Euglena & & & & & & & \\
\hline \multicolumn{8}{|l|}{ Chrysophyta } \\
\hline Hydrurus foetidus & & & & $a / 3$ & & & \\
\hline Tribonema & & $f / 3$ & & $c / 4$ & $\mathrm{c} / 2$ & $\mathrm{c} / 5$ & \\
\hline \multicolumn{8}{|l|}{ Vaucheria } \\
\hline Bacillariophyta & $f / 2$ & $d / 1$ & $a / 2$ & $d / 2$ & $a / 1$ & $d / 1$ & $a / 2$ \\
\hline No. Non-Diatom Genera & 8 & 10 & 11 & 7 & 3 & 5 & 5 \\
\hline
\end{tabular}


Table 4. Relative abundance of cells and ordinal rank by biovolume of diatoms (Division Bacillariophyta) and genera of non-diatom algae in periphyton samples collected from the Big Hole River TMDL Planning Area in 2003: $d$ = dominant, $a=$ abundant, $f=$ frequent, $c=$ common; $o=$ occasional; $r=$ rare. (continued)

Taxa

PINEC02 FOXC01 FOXC02 FSHTC01 FSHTC02 LMCHC01 LMCHC02

Cyanophyta

Amphithrix

Anabaena

$\mathrm{o} / 7$

$\mathrm{o} / 5$

$0 / 7$

Calothrix

Chamaesiphon

Merismopedia

Nodularia

Nostoc

$\mathrm{c} / 4$

$f / 2$

$0 / 4$

$\mathrm{a} / 3$

$1 / 8$

Oscillatoria

$\mathrm{f} / 2$

o/9

o/6

o/7

Phormidium

Symploca

Tolypothrix

o/6

$\mathrm{c} / 3$

\section{Rhodophyta}

Audouinella

o/5

$0 / 4$

\section{Chlorophyta}

Ankistrodesmus

Cladophora

Closterium

$\mathrm{c} / 3$

$c / 3$

$f / 2$

c/5

$\mathrm{c} / 4$

$\mathrm{o} / 2$

c/6

Cosmarium

Draparnaldia

Hormidium

Microspora

Mougeotia

Oedogonium

o/6

$0 / 8$

$0 / 8$

Pediastrum

Prasiola

Scenedesmus

Spirogyra

Staurastrum

Stigeoc/onium

Tetraspora

Ulothrix

Zygnema

\section{$r / 8$}

$0 / 6$

$c / 5$

$\mathrm{c} / 4$

$r / 9$

$0 / 6$

$d / 1$

c/5

Euglenophyta

Euglena

Chrysophyta

Hydrurus foetidus

Tribonema

$a / 3$

$d / 1$

$0 / 5$

$f / 3$

Vaucheria

$\mathrm{d} / 1$

Bacillariophyta

a/1

$\mathrm{a} / 1$

$\mathrm{a} / 1$

$d / 2$

$d / 2$

$f / 1$

$\mathrm{a} / 2$

No. Non-Diatom Genera

7

5

4

8

9

5 
Table 4. Relative abundance of cells and ordinal rank by biovolume of diatoms (Division Bacillariophyta) and genera of non-diatom algae in periphyton samples collected from the Big Hole River TMDL Planning Area in 2003: $d=$ dominant, $a=$ abundant, $f=$ frequent,$c=$ common; $o=$ occasional; $r=$ rare. (continued)

\begin{tabular}{|c|c|c|c|c|c|c|c|}
\hline Taxa & DLNOC01 & DLNOCO2 & DLNOC03 & CHRGC01 & ELKHC01 & ELKHC02 & FRANC01 \\
\hline \multicolumn{8}{|l|}{ Cyanophyta } \\
\hline \multicolumn{8}{|l|}{ Amphithrix } \\
\hline \multicolumn{8}{|l|}{ Anabaena } \\
\hline Calothrix & & & & & $\mathbf{c} / 3$ & $c / 3$ & \\
\hline \multicolumn{8}{|l|}{ Chamaesiphon } \\
\hline \multicolumn{8}{|l|}{ Merismopedia } \\
\hline \multicolumn{8}{|l|}{ Nodularia } \\
\hline \multicolumn{8}{|l|}{ Nostoc } \\
\hline Oscillatoria & $\mathrm{c} / 2$ & $\mathrm{o} / 2$ & & $\mathrm{o} / 5$ & & $\mathrm{o} / 6$ & \\
\hline Phormidium & & & & & & $f / 4$ & \\
\hline \multicolumn{8}{|l|}{ Symploca } \\
\hline \multicolumn{8}{|l|}{ Tolypothrix } \\
\hline \multirow{2}{*}{\multicolumn{8}{|c|}{$\begin{array}{l}\text { Rhodophyta } \\
\text { Audouinella }\end{array}$}} \\
\hline & & & & & & & \\
\hline \multicolumn{8}{|l|}{ Chlorophyta } \\
\hline \multicolumn{8}{|l|}{ Ankistrodesmus } \\
\hline \multicolumn{8}{|l|}{ Cladophora } \\
\hline Closterium & & $r / 3$ & $\mathrm{o} / 3$ & $\mathrm{o} / 3$ & & & $\mathrm{o} / 3$ \\
\hline Cosmarium & & & & & & $\mathrm{o} / 5$ & \\
\hline \multicolumn{8}{|l|}{ Draparnaldia } \\
\hline \multicolumn{8}{|l|}{ Hormidium } \\
\hline \multicolumn{8}{|l|}{ Microspora } \\
\hline Mougeotia & & & & $\mathrm{o} / 4$ & & $a / 2$ & \\
\hline \multicolumn{8}{|l|}{ Oedogonium } \\
\hline \multicolumn{8}{|l|}{ Pediastrum } \\
\hline \multicolumn{8}{|l|}{ Prasiola } \\
\hline \multicolumn{8}{|l|}{ Scenedesmus } \\
\hline \multicolumn{8}{|l|}{ Spirogyra } \\
\hline \multicolumn{8}{|l|}{ Staurastrum } \\
\hline \multicolumn{8}{|l|}{ Stigeoclonium } \\
\hline \multicolumn{8}{|l|}{ Tetraspora } \\
\hline Ulothrix & & & & & $f / 2$ & & \\
\hline Zygnema & & & $d / 1$ & & & & \\
\hline Euglenophyta & & & & & & & \\
\hline Euglena & & & & & & & \\
\hline Chrysophyta & & & & & & & \\
\hline Hydrurus foetidus & & & & & & & \\
\hline Tribonema & & & & $\mathrm{o} / 2$ & & & $\mathrm{o} / 2$ \\
\hline Vaucheria & & & & & & & \\
\hline Bacillariophyta & $c / 1$ & $c / 1$ & $c / 2$ & $a / 1$ & $a / 1$ & $a / 1$ & $a / 1$ \\
\hline No. Non-Diatom Genera & 1 & 2 & 2 & 4 & 2 & 5 & 2 \\
\hline
\end{tabular}


Table 4. Relative abundance of cells and ordinal rank by biovolume of diatoms (Division Bacillariophyta) and genera of non-diatom algae in periphyton samples collected from the Big Hole River TMDL Planning Area in 2003: $d=$ dominant, $a=$ abundant, $f=$ frequent,$c=$ common; $o=$ occasional; $r=$ rare. (continued)

\begin{tabular}{|c|c|c|c|c|c|c|c|}
\hline \multirow{2}{*}{\multicolumn{8}{|c|}{ FRANC02 DIVDC01 DIVDC02 SOAPC01 SOAPC02 MCLNC01 GROSC01 }} \\
\hline & & & & & & & \\
\hline Amphithrix & & & $f / 3$ & & & & \\
\hline Anabaena & & & & & & & \\
\hline Calothrix & & & & & & $r / 2$ & \\
\hline Chamaesiphon & & & & & & & \\
\hline Merismopedia & & & & & & & \\
\hline Nodularia & & & & & & & \\
\hline Nostoc & & & $\mathrm{f} / 2$ & & & & \\
\hline Oscillatoria & & $0 / 8$ & & & $r / 2$ & & \\
\hline Phormidium & & & & & & & \\
\hline Symploca & & & $\mathrm{c} / 5$ & & & & \\
\hline Tolypothrix & & & & & & & \\
\hline \multicolumn{8}{|l|}{ Rhodophyta } \\
\hline Audouinella & & & & & & & $0 / 2$ \\
\hline \multicolumn{8}{|l|}{ Chlorophyta } \\
\hline Ankistrodesmus & $\mathrm{c} / 5$ & $0 / 9$ & & & & & \\
\hline Cladophora & $d / 1$ & & & & & & \\
\hline Closterium & $0 / 3$ & & & & & & \\
\hline Cosmarium & & $c / 5$ & o/6 & & & & . \\
\hline Draparnaldia & & & & & & & \\
\hline Hormidium & & & & & & & \\
\hline $\begin{array}{l}\text { Microspora } \\
\text { Mougeotia }\end{array}$ & & & & & & & \\
\hline Medogonium & & $0 / 4$ & & & & & \\
\hline Pediastrum & $r / 6$ & & & & & & \\
\hline Prasiola & & & & & & & \\
\hline Scenedesmus & $c / 4$ & $c / 6$ & $0 / 7$ & & & & \\
\hline Spirogyra & & & & & & & \\
\hline Staurastrum & & $\mathrm{c} / 7$ & & & & & \\
\hline Stigeoclonium & & $\mathrm{a} / 2$ & & & & & \\
\hline Tetraspora & & & & & & & \\
\hline Ulothrix & & & & & & & \\
\hline Zygnema & & & & & & & \\
\hline \multicolumn{8}{|l|}{ Euglenophyta } \\
\hline Euglena & & $r / 10$ & & & & & \\
\hline \multirow{2}{*}{\multicolumn{8}{|c|}{$\begin{array}{l}\text { Chrysophyta } \\
\text { Hydrurus foetidus }\end{array}$}} \\
\hline & & & & & & & \\
\hline Tribonema & & $f / 3$ & $c / 4$ & & & & \\
\hline Vaucheria & & & & & & & \\
\hline Bacillariophyta & $a / 2$ & $d / 1$ & $a / 1$ & $a / 1$ & $f / 1$ & $c / 1$ & $c / 1$ \\
\hline No. Non-Diatom Genera & 5 & 9 & 6 & 0 & 1 & 1 & 1 \\
\hline
\end{tabular}


Table 4. Relative abundance of cells and ordinal rank by biovolume of diatoms (Division Bacillariophyta) and genera of non-diatom algae in periphyton samples collected from the Big Hole River TMDL Planning Area in 2003: $d$ = dominant, $a=$ abundant, $f$ = frequent, $c=$ common; $o$ = occasional; $r=$ rare. (concluded)

\begin{tabular}{|c|c|c|c|c|c|c|c|}
\hline Taxa & LOSTC01 & LOSTC02 & SWLGC01 & SWLGC02 & CAMPC01 & CAMPC02 & CAMPCO3 \\
\hline \multicolumn{8}{|l|}{ Cyanophyta } \\
\hline \multicolumn{8}{|l|}{ Amphithrix } \\
\hline \multicolumn{8}{|l|}{ Anabaena } \\
\hline \multicolumn{8}{|l|}{ Calothrix } \\
\hline \multicolumn{8}{|l|}{ Chamaesiphon } \\
\hline \multicolumn{8}{|l|}{ Merismopedia } \\
\hline \multicolumn{8}{|l|}{ Nodularia } \\
\hline \multicolumn{8}{|l|}{ Nostoc } \\
\hline Oscillatoria & & & & o/7 & $c / 2$ & & $\mathrm{c} / 3$ \\
\hline \multicolumn{8}{|l|}{ Phormidium } \\
\hline \multicolumn{8}{|l|}{ Symploca } \\
\hline \multicolumn{8}{|l|}{ Tolypothrix } \\
\hline \multirow{2}{*}{\multicolumn{8}{|c|}{$\begin{array}{l}\text { Rhodophyta } \\
\text { Audouinella }\end{array}$}} \\
\hline & & & & & & & \\
\hline \multicolumn{8}{|l|}{ Chlorophyta } \\
\hline \multicolumn{8}{|l|}{ Ankistrodesmus } \\
\hline \multicolumn{8}{|l|}{ Cladophora } \\
\hline Closterium & & & & $\mathrm{o} / 5$ & & $0 / 4$ & $\mathrm{c} / 2$ \\
\hline Cosmarium & & & & o/6 & & & \\
\hline \multicolumn{8}{|l|}{ Draparnaldia } \\
\hline \multicolumn{8}{|l|}{ Hormidium } \\
\hline Microspora & & & & & & $c / 3$ & \\
\hline \multicolumn{8}{|l|}{ Mougeotia } \\
\hline Oedogonium & $0 / 2$ & & & $c / 4$ & & & \\
\hline \multicolumn{8}{|l|}{ Pediastrum } \\
\hline \multicolumn{8}{|l|}{ Prasiola } \\
\hline \multicolumn{8}{|l|}{ Scenedesmus } \\
\hline Spirogyra & & & & $c / 3$ & & $\mathrm{c} / 2$ & \\
\hline \multicolumn{8}{|l|}{ Staurastrum } \\
\hline \multicolumn{8}{|l|}{ Stigeoclonium } \\
\hline \multicolumn{8}{|l|}{ Tetraspora } \\
\hline Ulothrix & & & & & & & \\
\hline Zygnema & & & & & & & \\
\hline Euglenophyta & & & & & & & \\
\hline Euglena & & & & & & & \\
\hline Chrysophyta & & & & & & & \\
\hline Hydrurus foetidus & & & & & & & \\
\hline Tribonema & & & $0 / 2$ & $f / 2$ & & & \\
\hline Vaucheria & & & & & & & \\
\hline Bacillariophyta & $\alpha / 1$ & $\mathrm{c} / 1$ & $\mathrm{c} / 1$ & $d / 1$ & $a / 1$ & $a / 1$ & $f / 1$ \\
\hline No. Non-Diatom Genera & 1 & 0 & 1 & 6 & 1 & 3 & 2 \\
\hline
\end{tabular}


Table 5. Percent abundance of major diatom species ${ }^{1}$ and values of selected diatom association metrics for periphyton samples collected from the Big Hole River TMDL Planning Area in 2003. Underlined values indicate minor stress; bold values indicate moderate stress; underlined and bold values indicate severe stress; all other values indicate no stress and full support of aquatic life uses when compared to biocriteria (thresholds) in Table 2. Observed stress may be natural or anthropogenic.

\begin{tabular}{|c|c|c|c|c|c|c|c|}
\hline Species/Metric ${ }^{2}$ & DOLTC01 & DOLTC02 & MCVYC01 & MCVYC02 & SWMPC01 & SWMPCO2 & WRMSC01 \\
\hline Achnanthidium affine & & & & & & & \\
\hline Ach. minutissimum & & & & & & & 7.54 \\
\hline Aulacoseira alpigena & & & & & & & \\
\hline Cocconeis placentula & & & & & & & \\
\hline Diatoma mesodon & 18.13 & & & & & & \\
\hline Encyonema silesiacum & & & & & & & \\
\hline Epithemia sorex & & & & & & & \\
\hline Fragilaria capucina & & & & & & & \\
\hline Fragilaria nitzschioides & & & & & & & \\
\hline Fragilaria vaucheriae & 7.83 & 9.57 & 16.02 & & & 8.60 & \\
\hline Melosira varians & & & & & & & \\
\hline Meridion circulare & & & & & & & \\
\hline Navicula capitatoradiata & & & & & & & \\
\hline Navicula minima & & & & 5.92 & & 9.59 & 16.72 \\
\hline Navicula reichardtiana & & & & & & & \\
\hline Nitzschia archibaldii & & & & & 18.63 & & \\
\hline Nitzschia inconspicua & & & & & & 7.76 & \\
\hline Nitzschia linearis & & & & & & & \\
\hline$\overline{\text { Nitzschia palea }}$ & & & & & 17.07 & & \\
\hline Nitzschia perminuta & & & & & 9.82 & & \\
\hline Planothidium spp. & & & 8.01 & 5.03 & & 8.74 & \\
\hline $\begin{array}{l}\text { Pseudostaur. brevistriata } \\
\text { Rhoicosphenia abbreviata }\end{array}$ & & 11.16 & & 19.39 & & & 7.40 \\
\hline $\begin{array}{l}\text { Staurosira construens } \\
\text { Staurosirella leptostauron }\end{array}$ & 10.45 & 10.71 & & 28.90 & & 8.18 & 8.28 \\
\hline Staurosirella pinnata & & 9.11 & 6.25 & & & & \\
\hline Synedra ulna & & & & & & & \\
\hline No. of Species Counted & 64 & 59 & 75 & 55 & 67 & 57 & 61 \\
\hline Species Diversity & 4.84 & 4.93 & 5.22 & 4.03 & 4.61 & 4.75 & 4.79 \\
\hline Pollution Index & 2.67 & 2.54 & 2.31 & 2.67 & 1.93 & $\underline{2.23}$ & $\underline{2.46}$ \\
\hline Siltation Index & 9.83 & 18.68 & 25.59 & 15.44 & 75.53 & 31.88 & $\overline{27.22}$ \\
\hline Disturbance Index & 3.23 & 2.28 & 1.95 & 0.72 & $\overline{0.43}$ & 1.13 & 7.54 \\
\hline$\%$ Dominant Species & 18.13 & 11.16 & 16.02 & $\underline{28.90}$ & 18.63 & 9.59 & 16.72 \\
\hline$\%$ Abnormal Cells & $\underline{0.61}$ & $\underline{0.46}$ & 1.37 & $\underline{0.72}$ & $\underline{0.43}$ & 1.27 & 0.59 \\
\hline Similarity Index ${ }^{3}$ & $\overline{55.84}$ & $\overline{55.84}$ & $\overline{37.69}$ & $\overline{37.69}$ & $\overline{32.32}$ & $\overline{32.32}$ & $\overline{45.04}$ \\
\hline
\end{tabular}

${ }^{1}$ A major diatom species accounts for $9.0 \%$ or more of the cells at one or more stations in a sample set.

Values for major species are shown only where they equal or exceed $5.0 \%$ of the cells in that sample.

${ }^{2}$ Species that are sensitive to organic pollution are in italics; species that are somewhat tolerant of organic pollution are underlined; species that are very tolerant to organic pollution are in bold face type.

${ }^{3}$ Percent Community Similarity (Whittaker 1952) when compared to the diatom assemblage at the adjacent station on the same stream. 
Table 5. Percent abundance of major diatom species ${ }^{1}$ and values of selected diatom association metrics for periphyton samples collected from the Big Hole River TMDL Planning Area in 2003. Underlined values indicate minor stress; bold values indicate moderate stress; underlined and bold values indicate severe stress; all other values indicate no stress and full support of aquatic life uses when compared to biocriteria (thresholds) in Table 2. Observed stress may be natural or anthropogenic. (continued)

\begin{tabular}{|c|c|c|c|c|c|c|c|}
\hline Species/Metric ${ }^{2}$ & WRMSC02 & BGHNF01 & BGHNF02 & GOLDC01 & GOLDC02 & JERRC01 & PINEC01 \\
\hline \multicolumn{8}{|l|}{ Achnanthidium affine } \\
\hline Ach. minutissimum & 25.30 & 7.00 & & & & & \\
\hline \multicolumn{8}{|l|}{ Aulacoseira alpigena } \\
\hline \multicolumn{8}{|l|}{ Cocconeis placentula } \\
\hline \multicolumn{8}{|l|}{ Diatoma mesodon } \\
\hline \multicolumn{8}{|l|}{ Encyonema silesiacum } \\
\hline \multicolumn{8}{|l|}{ Epithemia sorex } \\
\hline \multicolumn{8}{|l|}{ Fragilaria capucina } \\
\hline \multicolumn{8}{|l|}{ Fragilaria nitzschioides } \\
\hline Fragilaria vaucheriae & 6.36 & & & 11.96 & 19.52 & 25.50 & 7.36 \\
\hline Melosira varians & & 8.00 & & & & & \\
\hline Meridion circulare & & & & & & & 8.59 \\
\hline \multicolumn{8}{|l|}{ Navicula capitatoradiata } \\
\hline \multicolumn{8}{|l|}{ Navicula minima } \\
\hline \multicolumn{8}{|l|}{ Navicula reichardtiana } \\
\hline Nitzschia archibaldii & & & 20.67 & & & & 6.60 \\
\hline \multicolumn{8}{|l|}{ Nitzschia inconspicua } \\
\hline \multicolumn{8}{|l|}{ Nitzschia linearis } \\
\hline \multicolumn{8}{|l|}{$\overline{\text { Nitzschia palea }}$} \\
\hline Planothidium spp. & & & & 13.40 & 12.52 & & \\
\hline $\begin{array}{l}\text { Pseudostaur. brevistriata } \\
\text { Rhoicosphenia abbreviata }\end{array}$ & 7.81 & 12.43 & 18.04 & 14.19 & 9.39 & 7.25 & 16.41 \\
\hline Staurosira construens & 6.23 & 9.57 & 10.85 & & & 12.21 & 12.88 \\
\hline Staurosirella leptostauron & & & & 5.10 & 9.84 & & \\
\hline Staurosirella pinnata & 6.62 & 5.00 & & & & 13.56 & \\
\hline \multicolumn{8}{|l|}{ Synedra ulna } \\
\hline No. of Species Counted & 58 & 64 & 56 & 44 & 49 & 47 & 52 \\
\hline Species Diversity & 4.44 & 4.94 & 4.24 & 4.27 & 4.29 & 3.96 & 4.52 \\
\hline Pollution Index & 2.59 & 2.52 & $\underline{2.46}$ & $\underline{2.44}$ & $\underline{2.44}$ & 2.52 & 2.63 \\
\hline Siltation Index & $\underline{27.42}$ & $\underline{23.00}$ & $\underline{36.66}$ & 18.02 & 16.10 & 6.04 & $\underline{20.86}$ \\
\hline Disturbance Index & $\underline{25.30}$ & 7.00 & 4.55 & 4.63 & 2.98 & 0.54 & 1.84 \\
\hline$\%$ Dominant Species & $\underline{25.30}$ & 12.43 & 20.67 & 14.19 & 19.52 & $\underline{25.50}$ & 16.41 \\
\hline$\%$ Abnormal Cells & 1.32 & $\underline{0.14}$ & $\underline{0.73}$ & $\underline{0.64}$ & 1.49 & 1.07 & $\underline{0.46}$ \\
\hline Similarity Index ${ }^{3}$ & 45.04 & 54.35 & 54.35 & 71.97 & 71.97 & & 62.30 \\
\hline
\end{tabular}

${ }^{1}$ A major diatom species accounts for $9.0 \%$ or more of the cells at one or more stations in a sample set. Values for major species are shown only where they equal or exceed $5.0 \%$ of the cells in that sample.

${ }^{2}$ Species that are sensitive to organic pollution are in italics; species that are somewhat tolerant of organic pollution are underlined; species that are very tolerant to organic pollution are in bold face type.

${ }^{3}$ Percent Community Similarity (Whittaker 1952) when compared to the diatom assemblage at the adjacent station on the same stream. 
Table 5. Percent abundance of major diatom species ${ }^{1}$ and values of selected diatom association metrics for periphyton samples collected from the Big Hole River TMDL Planning Area in 2003. Underlined values indicate minor stress; bold values indicate moderate stress; underlined and bold values indicate severe stress; all other values indicate no stress and full support of aquatic life uses when compared to biocriteria (thresholds) in Table 2. Observed stress may be natural or anthropogenic. (continued)

\begin{tabular}{|c|c|c|c|c|c|c|c|}
\hline Species/Metric ${ }^{2}$ & PINEC02 & F0XC01 & $\mathrm{FOXC02}$ & FSHTC01 & FSHTC02 & LMCHC01 & $\mathrm{LMCHCO} 2$ \\
\hline \multicolumn{8}{|l|}{ Achnanthidium affine } \\
\hline Ach. minutissimum & & & & & & 12.95 & 7.31 \\
\hline Aulacoseira alpigena & & & & & & 12.13 & 8.71 \\
\hline Cocconeis placentula & & & 7.79 & & & & \\
\hline \multicolumn{8}{|l|}{ Diatoma mesodon } \\
\hline \multicolumn{8}{|l|}{ Encyonema silesiacum } \\
\hline \multicolumn{8}{|l|}{ Epithemia sorex } \\
\hline Fragilaria capucina & & & & 13.11 & & & \\
\hline \multicolumn{8}{|l|}{ Fragilaria nitzschioides } \\
\hline$\frac{\text { Fragilaria vaucheriae }}{\text { Melosira varians }}$ & 6.93 & 7.15 & 17.06 & 9.00 & 9.82 & 5.25 & 12.91 \\
\hline \multicolumn{8}{|l|}{ Meridion circulare } \\
\hline \multicolumn{8}{|l|}{ Navicula capitatoradiata } \\
\hline \multicolumn{8}{|l|}{$\begin{array}{l}\text { Navicula minima } \\
\text { Navicula reichardtiana }\end{array}$} \\
\hline Navicula reichardtiana & & & & & & & \\
\hline \multicolumn{8}{|l|}{ Nitzschia archibaldii } \\
\hline \multicolumn{8}{|l|}{ Nitzschia inconspicua } \\
\hline \multicolumn{8}{|l|}{ Nitzschia linearis } \\
\hline \multicolumn{8}{|l|}{ Nitzschia palea } \\
\hline Planothidium spp. & 6.61 & 6.38 & & & & & \\
\hline $\begin{array}{l}\text { Pseudostaur. brevistriata } \\
\text { Rhoicosphenia abbreviata }\end{array}$ & 13.39 & & & 12.16 & 16.26 & & 6.22 \\
\hline Staurosira construens & 11.97 & 18.20 & 9.12 & 9.48 & 9.66 & 8.69 & \\
\hline Staurosirella leptostauron & & & & & & & \\
\hline Staurosirella pinnata & 10.24 & & & & & & \\
\hline Synedra ulna & & 6.53 & & 10.43 & & & 12.91 \\
\hline No. of Species Counted & 65 & 48 & 58 & 65 & 71 & 81 & 90 \\
\hline Species Diversity & 4.63 & 4.53 & 4.76 & 4.69 & 5.00 & 5.15 & 5.05 \\
\hline Pollution Index & 2.58 & $\underline{2.48}$ & $\underline{2.42}$ & $\underline{2.40}$ & 2.51 & 2.80 & 2.60 \\
\hline Siltation Index & $\underline{20.94}$ & $\underline{20.22}$ & $\overline{30.15}$ & $\overline{12.95}$ & 21.63 & 14.26 & 8.55 \\
\hline Disturbance Index & 2.36 & 0.00 & 0.29 & 1.90 & 2.45 & 12.95 & 7.31 \\
\hline$\%$ Dominant Species & 13.39 & 18.20 & 17.06 & 13.11 & 16.26 & 12.95 & 12.91 \\
\hline$\%$ Abnormal Cells & 1.26 & 0.00 & $\underline{0.59}$ & $\underline{0.79}$ & 0.00 & 0.00 & 1.56 \\
\hline Similarity Index ${ }^{3}$ & 62.30 & 54.39 & 54.39 & 64.04 & 64.04 & 55.21 & 55.21 \\
\hline
\end{tabular}

${ }^{1}$ A major diatom species accounts for $9.0 \%$ or more of the cells at one or more stations in a sample set.

Values for major species are shown only where they equal or exceed $5.0 \%$ of the cells in that sample.

${ }^{2}$ Species that are sensitive to organic pollution are in italics; species that are somewhat tolerant of organic pollution are underlined; species that are very tolerant to organic pollution are in bold face type.

${ }^{3}$ Percent Community Similarity (Whittaker 1952) when compared to the diatom assemblage at the adjacent station on the same stream. 
Table 5. Percent abundance of major diatom species ${ }^{1}$ and values of selected diatom association metrics for periphyton samples collected from the Big Hole River TMDL Planning Area in 2003. Underlined values indicate minor stress; bold values indicate moderate stress; underlined and bold values indicate severe stress; all other values indicate no stress and full support of aquatic life uses when compared to biocriteria (thresholds) in Table 2. Observed stress may be natural or anthropogenic. (continued)

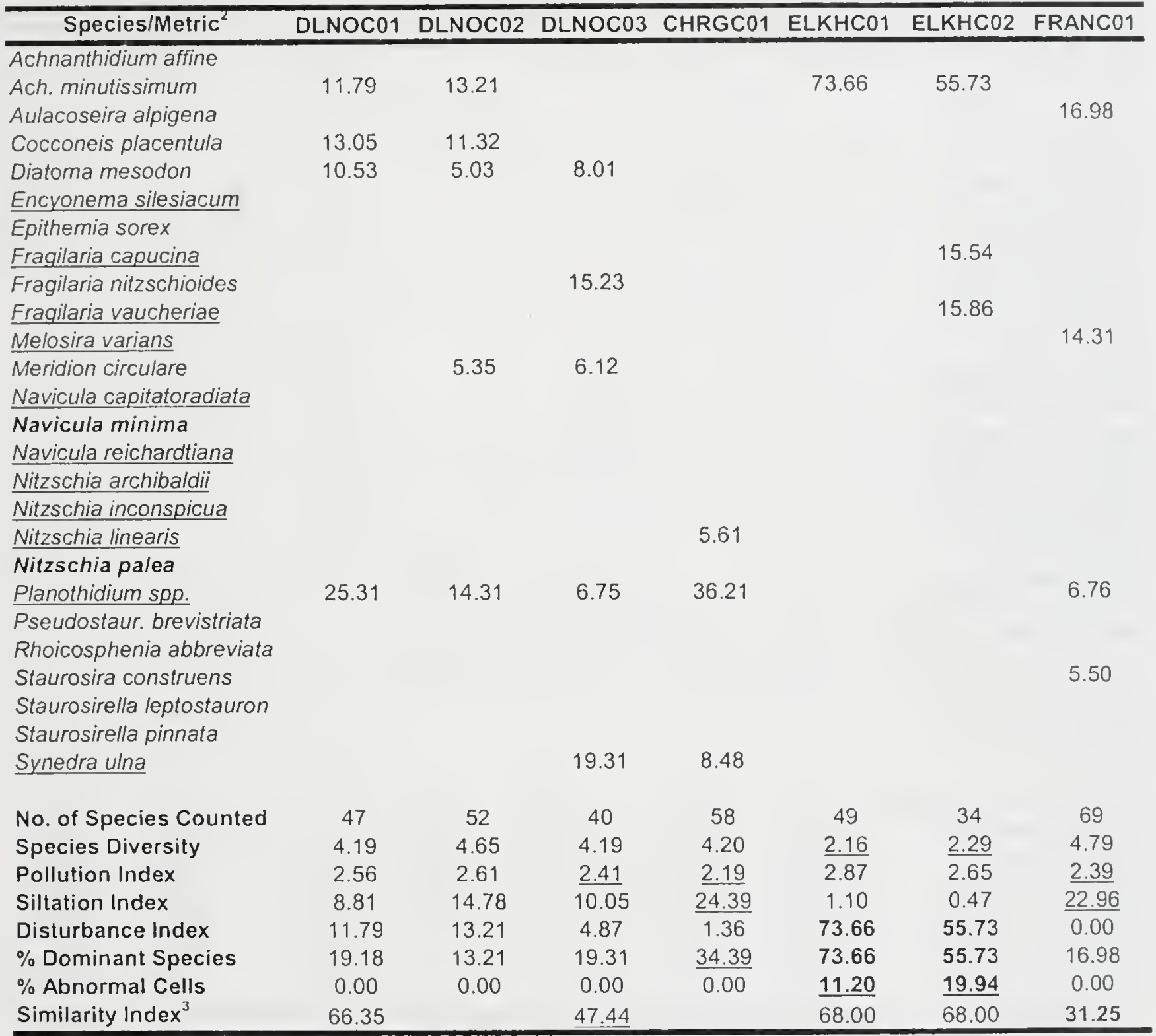

${ }^{1}$ A major diatom species accounts for $9.0 \%$ or more of the cells at one or more stations in a sample set. Values for major species are shown only where they equal or exceed $5.0 \%$ of the cells in that sample.

${ }^{2}$ Species that are sensitive to organic pollution are in italics; species that are somewhat tolerant of organic pollution are underlined; species that are very tolerant to organic pollution are in bold face type.

${ }^{3}$ Percent Community Similarity (Whittaker 1952) when compared to the diatom assemblage at the adjacent station on the same stream. 
Table 5. Percent abundance of major diatom species ${ }^{1}$ and values of selected diatom association metrics for periphyton samples collected from the Big Hole River TMDL Planning Area in 2003. Underlined values indicate minor stress; bold values indicate moderate stress; underlined and bold values indicate severe stress; all other values indicate no stress and full support of aquatic life uses when compared to biocriteria (thresholds) in Table 2. Observed stress may be natural or anthropogenic. (continued)

\begin{tabular}{|c|c|c|c|c|c|c|c|}
\hline Species/Metric ${ }^{2}$ & FRANC02 & DIVDC01 & DIVDC02 & SOAPC01 & SOAPC02 & MCLNC01 & GROSC01 \\
\hline \multicolumn{8}{|l|}{ Achnanthidium affine } \\
\hline Ach. minutissimum & & & & & 10.41 & 7.53 & \\
\hline \multicolumn{8}{|l|}{ Aulacoseira alpigena } \\
\hline Cocconeis placentula & & & 19.11 & 10.45 & 11.67 & 7.83 & 9.98 \\
\hline \multicolumn{8}{|l|}{ Diatoma mesodon } \\
\hline Encyonema silesiacum & & 5.20 & & & & & \\
\hline Epithemia sorex & 24.76 & & & & & & \\
\hline \multicolumn{8}{|l|}{ Fragilaria capucina } \\
\hline \multicolumn{8}{|l|}{ Fragilaria nitzschioides } \\
\hline \multicolumn{8}{|l|}{ Fragilaria vaucheriae } \\
\hline \multicolumn{8}{|l|}{ Melosira varians } \\
\hline Meridion circulare & & & & & 14.67 & & 8.74 \\
\hline \multicolumn{8}{|l|}{ Navicula capitatoradiata } \\
\hline \multicolumn{8}{|l|}{ Navicula minima } \\
\hline \multicolumn{8}{|l|}{ Navicula reichardtiana } \\
\hline \multicolumn{8}{|l|}{ Nitzschia archibaldii } \\
\hline \multicolumn{8}{|l|}{ Nitzschia inconspicua } \\
\hline Nitzschia linearis & & & & & & 7.22 & 6.08 \\
\hline \multicolumn{8}{|l|}{ Nitzschia palea } \\
\hline Planothidium spp. & & & 11.64 & 16.06 & 16.88 & 39.78 & 22.31 \\
\hline Pseudostaur. brevistriata & 5.17 & & & & & & \\
\hline Rhoicosphenia abbreviata & & 16.85 & 8.63 & & & & \\
\hline Staurosira construens & 26.18 & & 8.01 & 7.58 & & & \\
\hline Staurosirella leptostauron & & & & & & & \\
\hline Staurosirella pinnata & & & & & & & \\
\hline Synedra ulna & & & & & & & \\
\hline No. of Species Counted & 59 & 68 & 70 & 73 & 50 & 44 & 55 \\
\hline Species Diversity & 4.01 & 5.18 & 4.83 & 5.20 & 4.38 & 3.97 & 4.76 \\
\hline Pollution Index & 2.64 & $\underline{2.30}$ & 2.56 & $\underline{2.38}$ & 2.54 & $\underline{2.29}$ & $\underline{2.28}$ \\
\hline Siltation Index & $\underline{22.26}$ & $\overline{34.49}$ & 19.72 & $\overline{35.00}$ & $\underline{23.50}$ & 27.34 & $\overline{39.94}$ \\
\hline Disturbance Index & $\overline{1.72}$ & $\overline{0.79}$ & 1.23 & $\overline{2.88}$ & $\overline{10.41}$ & $\overline{7.53}$ & 2.50 \\
\hline$\%$ Dominant Species & 26.18 & 16.85 & 19.11 & 12.73 & 15.62 & 33.95 & 12.17 \\
\hline$\%$ Abnormal Cells & $\overline{0.00}$ & 0.00 & 0.00 & 0.00 & 0.00 & $\underline{0.92}$ & 0.00 \\
\hline Similarity Index ${ }^{3}$ & 31.25 & 46.22 & 46.22 & 63.05 & 63.05 & & \\
\hline
\end{tabular}

'A major diatom species accounts for $9.0 \%$ or more of the cells at one or more stations in a sample set. Values for major species are shown only where they equal or exceed $5.0 \%$ of the cells in that sample.

${ }^{2}$ Species that are sensitive to organic pollution are in italics; species that are somewhat tolerant of organic pollution are underlined; species that are very tolerant to organic pollution are in bold face type.

${ }^{3}$ Percent Community Similarity (Whittaker 1952) when compared to the diatom assemblage at the adjacent station on the same stream. 
Table 5. Percent abundance of major diatom species ${ }^{1}$ and values of selected diatom association metrics for periphyton samples collected from the Big Hole River TMDL Planning Area in 2003. Underlined values indicate minor stress; bold values indicate moderate stress; underlined and bold values indicate severe stress; all other values indicate no stress and full support of aquatic life uses when compared to biocriteria (thresholds) in Table 2. Observed stress may be natural or anthropogenic. (concluded)

\begin{tabular}{|c|c|c|c|c|c|c|c|}
\hline Species/Metric ${ }^{2}$ & LOSTC01 & LOSTC02 & SWLGC01 & SWLGC02 & CAMPC01 & CAMPC02 & CAMPC03 \\
\hline $\begin{array}{l}\text { Achnanthidium affine } \\
\text { Ach. minutissimum } \\
\text { Aulacoseira alpigena }\end{array}$ & 21.46 & 12.73 & & & 36.57 & & \\
\hline $\begin{array}{l}\text { Cocconeis placentula } \\
\text { Diatoma mesodon }\end{array}$ & & 24.84 & & & 6.33 & & 20.79 \\
\hline $\begin{array}{l}\text { Encyonema silesiacum } \\
\text { Epithemia sorex } \\
\text { Fragilaria capucina } \\
\text { Fragilaria nitzschioides }\end{array}$ & & & 9.26 & 14.90 & & & \\
\hline $\begin{array}{l}\text { Fragilaria vaucheriae } \\
\text { Melosira varians } \\
\text { Meridion circulare }\end{array}$ & & & & & & 7.54 & \\
\hline $\begin{array}{l}\text { Navicula capitatoradiata } \\
\text { Navicula minima } \\
\text { Navicula reichardtiana }\end{array}$ & 19.40 & & 10.52 & & & & \\
\hline Nitzschia archibaldii & & & 10.05 & & & & \\
\hline $\begin{array}{l}\text { Nitzschia inconspicua } \\
\text { Nitzschia linearis }\end{array}$ & 30.37 & & & & & 11.38 & 6.61 \\
\hline $\begin{array}{l}\text { Nitzschia palea } \\
\text { Planothidium spp. } \\
\text { Pseudostaur. brevistriata }\end{array}$ & & 15.06 & 12.87 & & & 18.61 & 7.24 \\
\hline $\begin{array}{l}\text { Rhoicosphenia abbreviata } \\
\text { Staurosira construens } \\
\text { Staurosirella leptostauron } \\
\text { Staurosirella pinnata }\end{array}$ & & 10.09 & & 9.03 & & & \\
\hline Synedra ulna & & & & 6.34 & & & \\
\hline No. of Species Counted & 39 & 34 & 67 & 75 & 60 & 71 & 79 \\
\hline Species Diversity & 3.31 & 3.87 & 5.14 & 5.08 & 4.05 & 5.00 & 4.99 \\
\hline Pollution Index & $\underline{2.12}$ & 2.65 & 2.22 & 2.37 & 2.55 & $\underline{2.29}$ & 2.53 \\
\hline Siltation Index & $\underline{63.43}$ & 22.98 & 46.00 & 25.04 & 24.69 & 39.08 & 38.58 \\
\hline Disturbance Index & 21.46 & 12.73 & 1.73 & 2.54 & 0.00 & 4.46 & 2.20 \\
\hline$\%$ Dominant Species & 30.37 & 24.84 & 10.52 & 14.90 & 36.57 & 11.38 & 20.79 \\
\hline$\%$ Abnormal Cells & $\underline{0.32}$ & 3.88 & 0.00 & 0.00 & 0.00 & 0.00 & 0.00 \\
\hline Similarity Index ${ }^{3}$ & $\overline{34.80}$ & 34.80 & 49.81 & 49.81 & 24.80 & & 32.52 \\
\hline
\end{tabular}

A major diatom species accounts for $9.0 \%$ or more of the cells at one or more stations in a sample set. Values for major species are shown only where they equal or exceed $5.0 \%$ of the cells in that sample.

${ }^{2}$ Species that are sensitive to organic pollution are in italics; species that are somewhat tolerant of organic pollution are underlined; species that are very tolerant to organic pollution are in bold face type.

${ }^{3}$ Percent Community Similarity (Whittaker 1952) when compared to the diatom assemblage at the adjacent station on the same stream. 


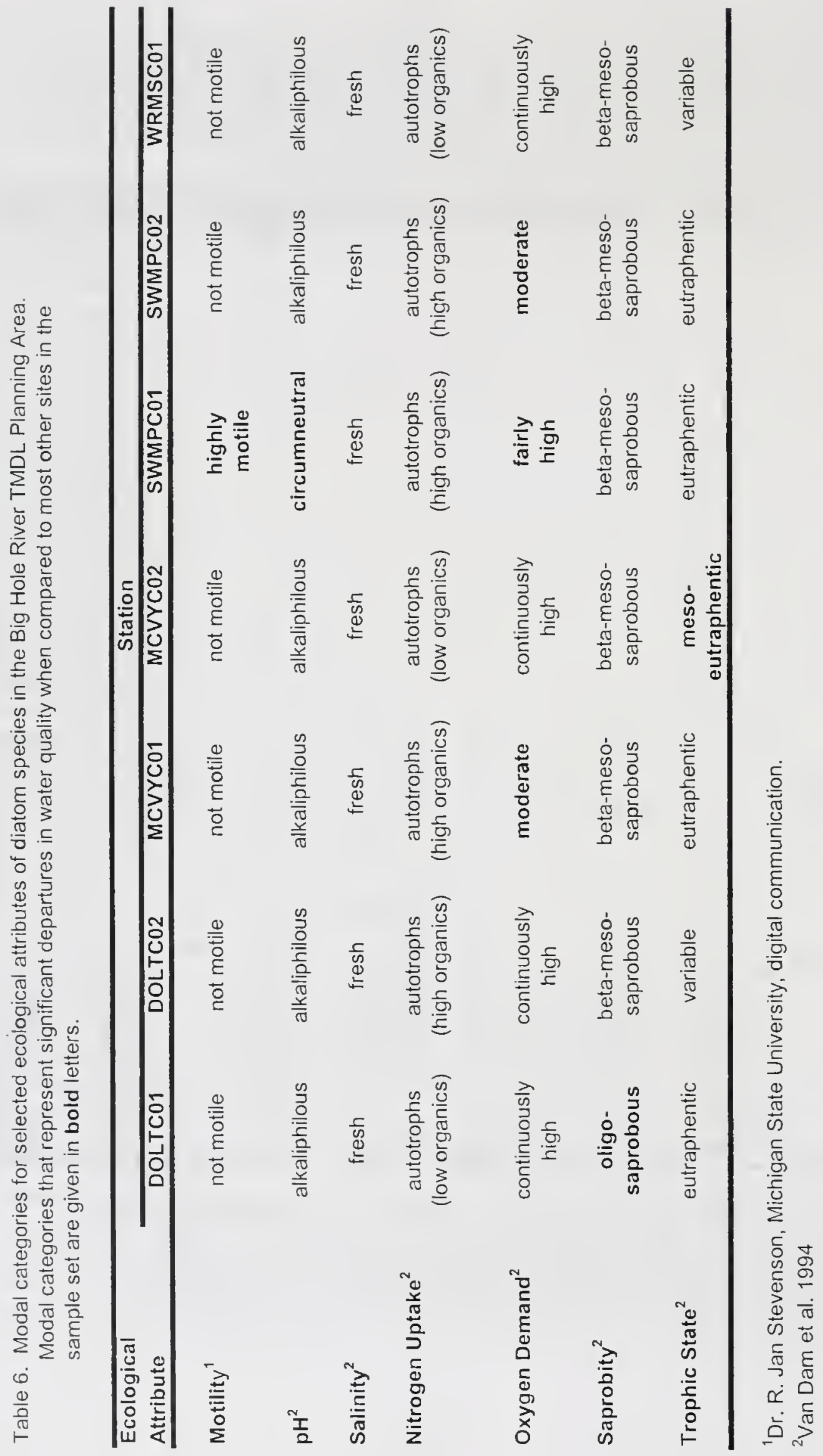




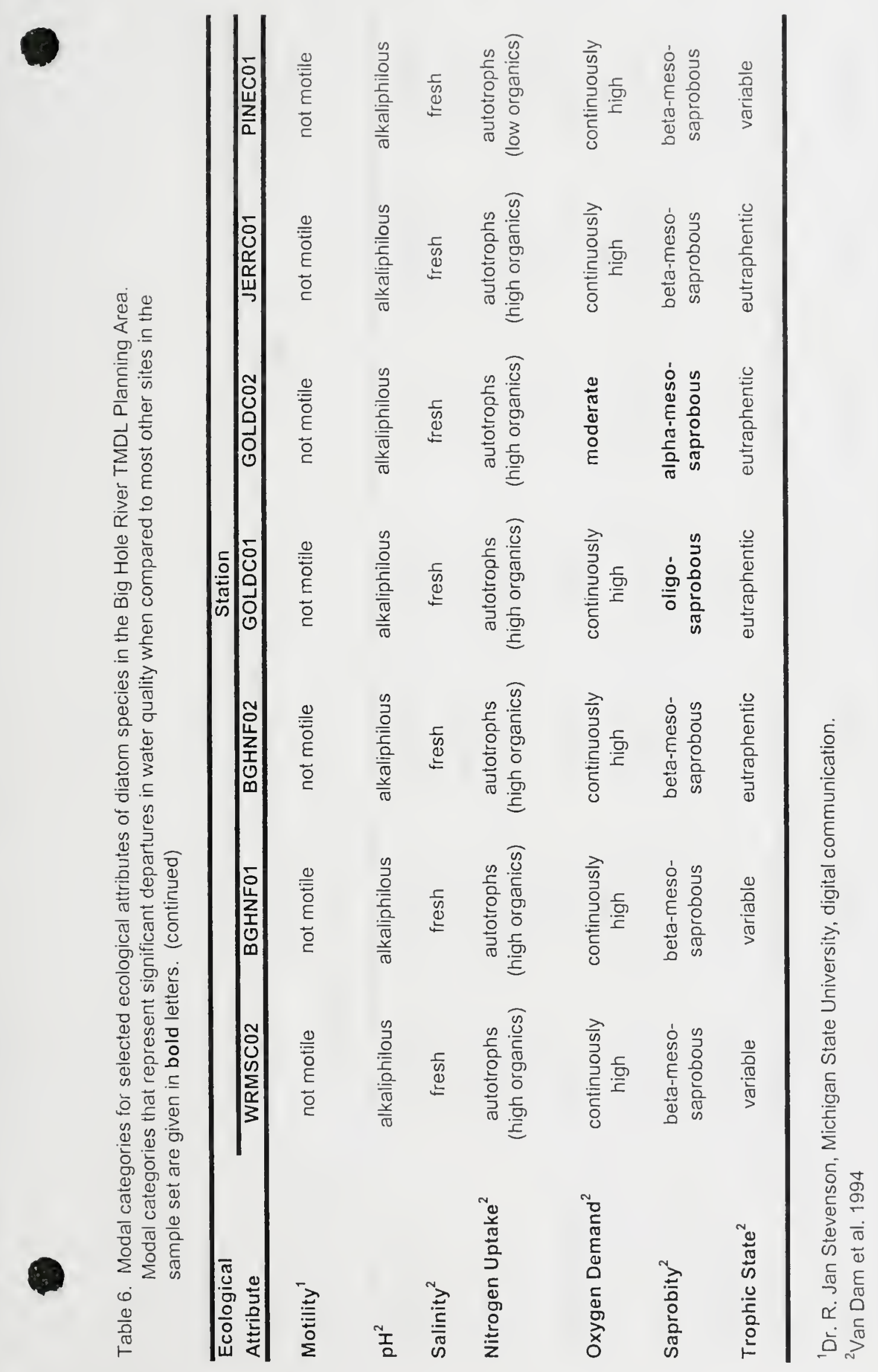




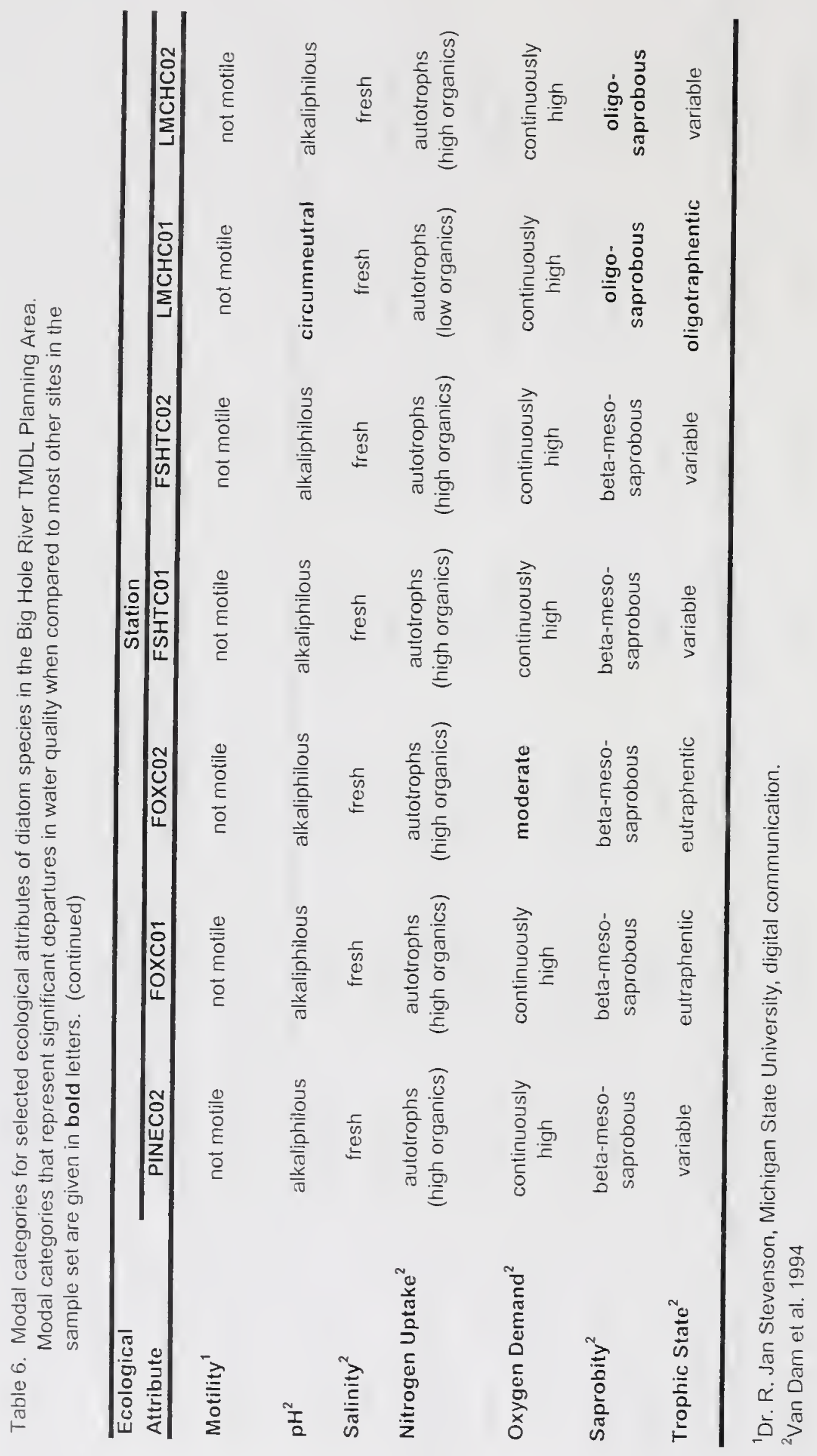




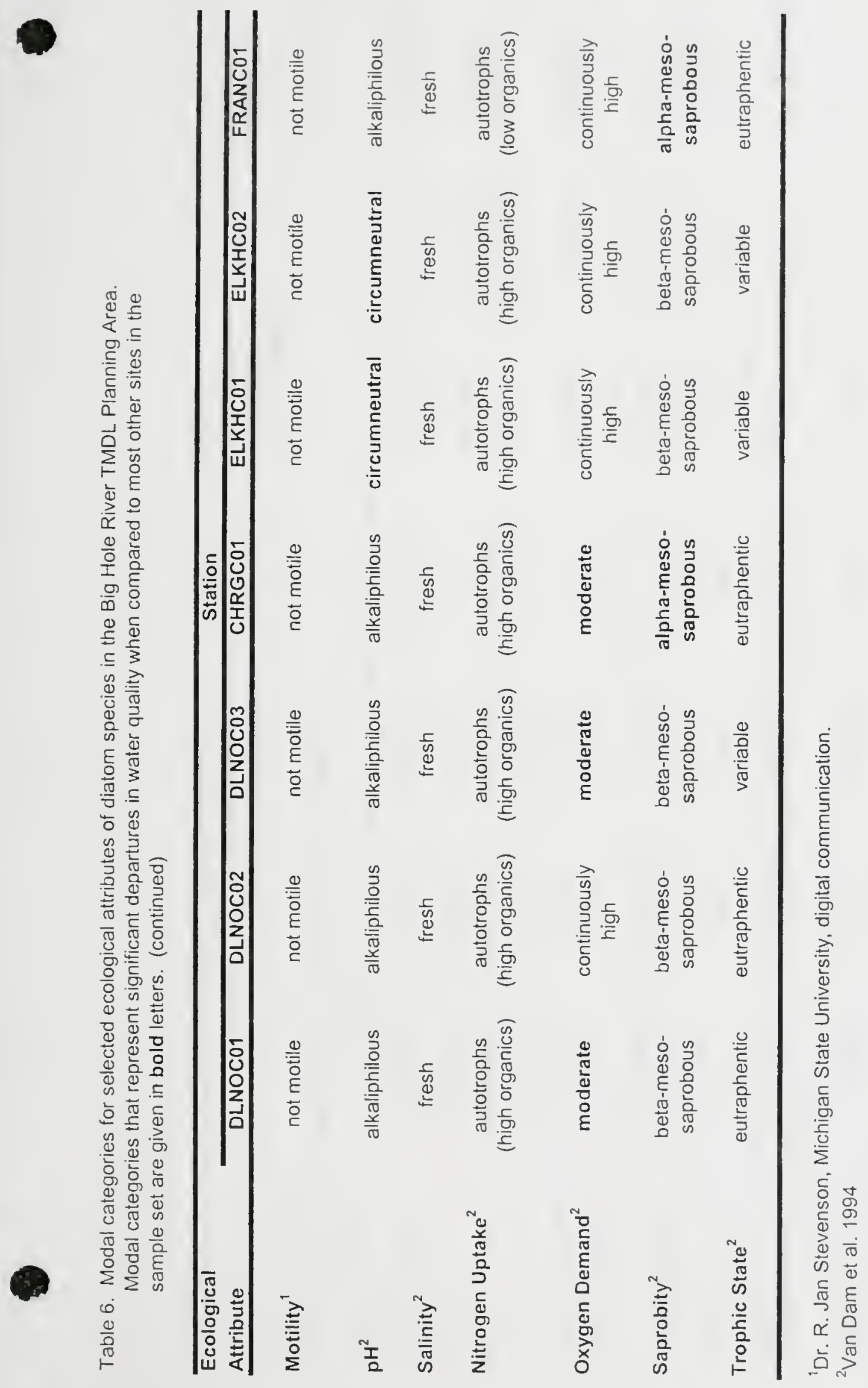




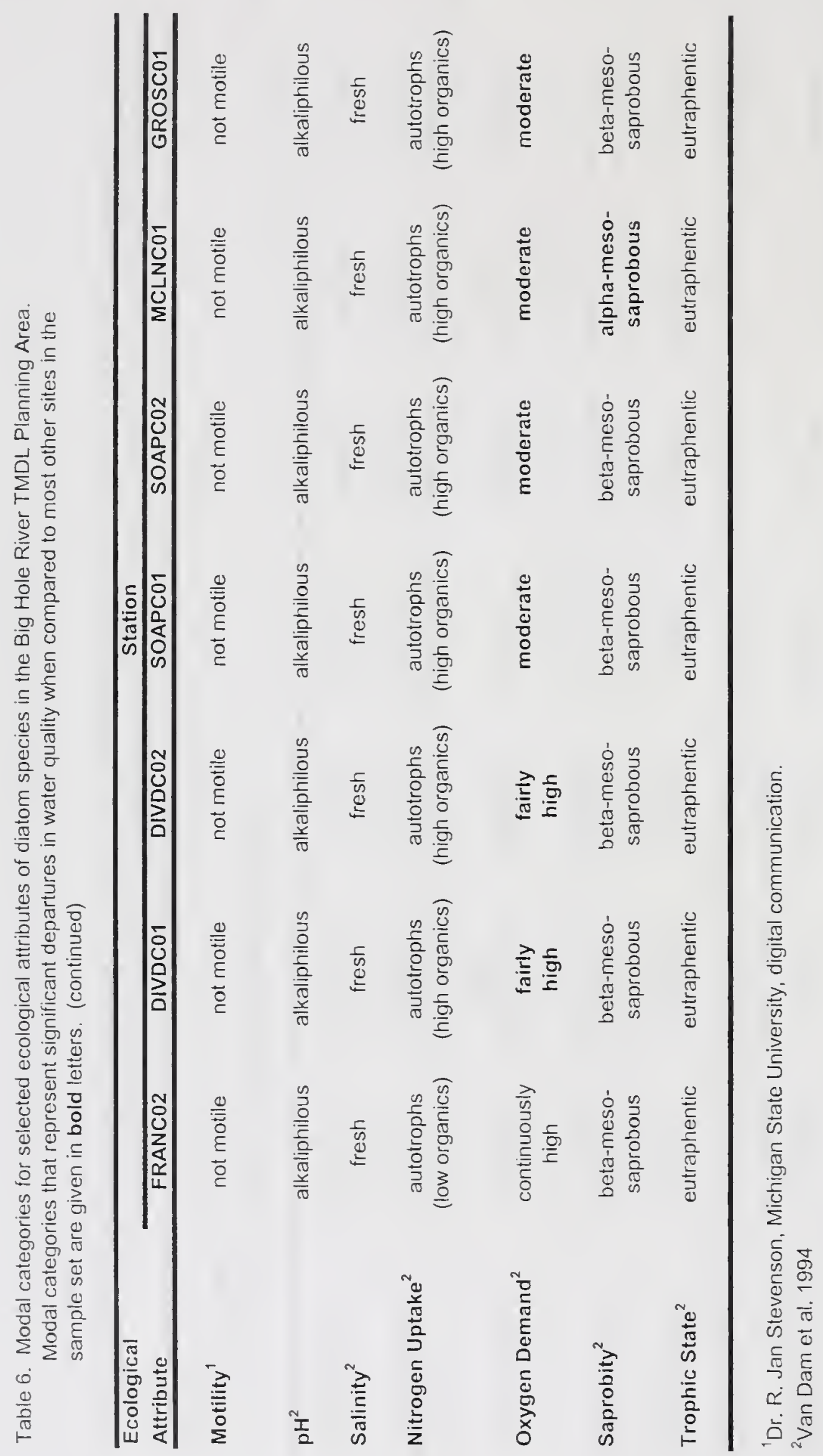




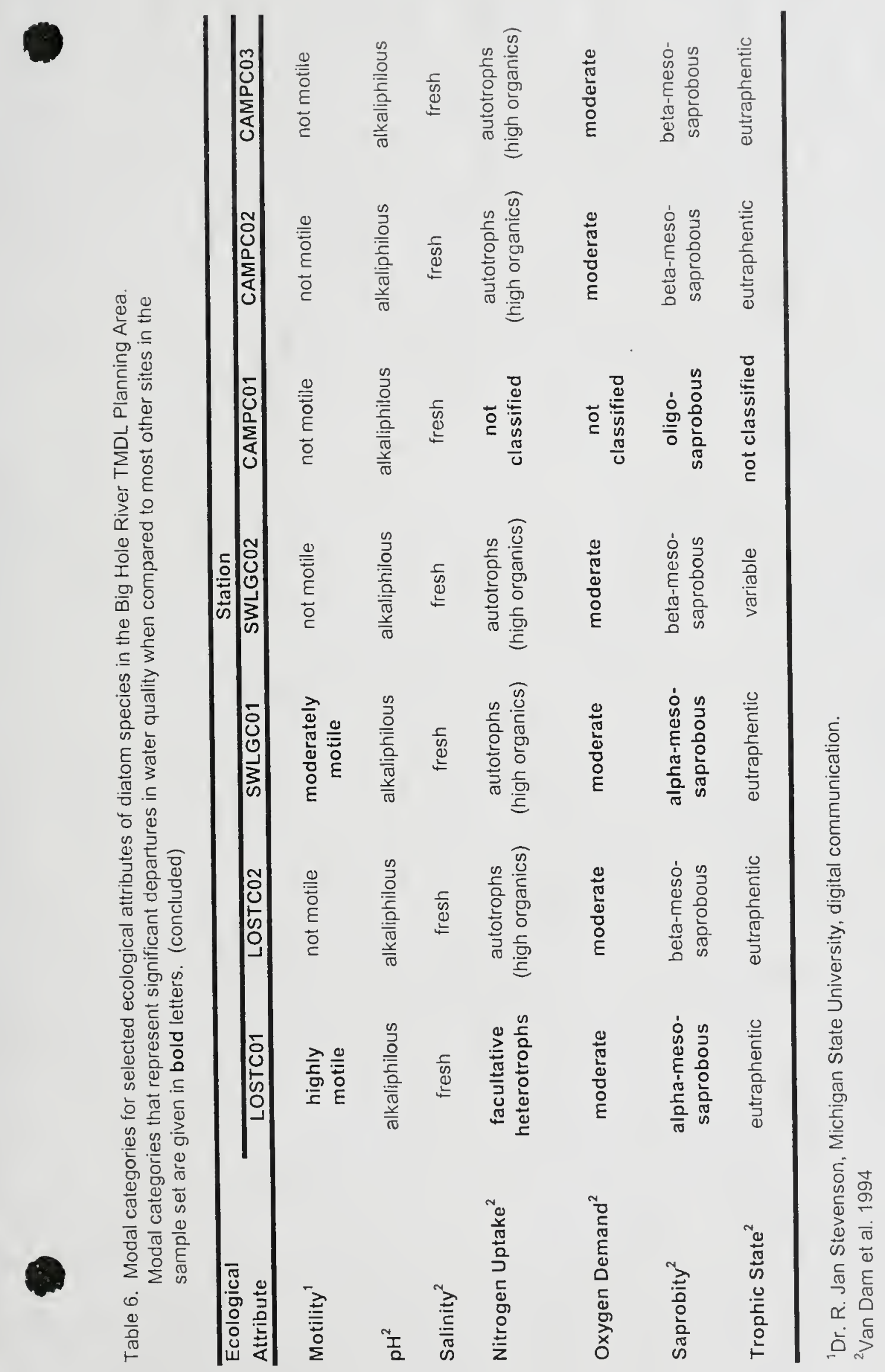


